Historic, archived document

Do not assume content reflects current scientific knowledge, policies, or practices. 



\section{New Products of the Trees}

\section{LUTHER BURBANK'S LATE INTRODUCTIONS}

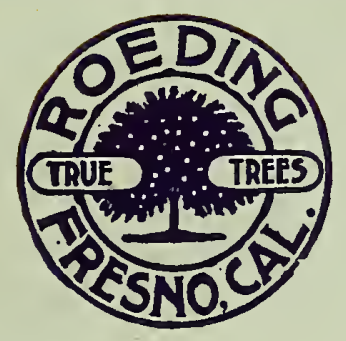

FOR SALE BY Fancher Creek Nurseries FRESNO, CALIFORNIA, U. S. A. 


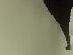




\section{New Products}

of the Trees

a Treatise on

\section{Luther Burbank's Late Introductions}

1907-1908 : THE FORMOSA, GAVIOTA AND VESUVIUS PLUM

1906 - 1907 : THE PARADOX

AND ROYAL BLACK WALNUT,

THE SANTA ROSA PLUM

AND THE RUTLAND PLUMCOT

"Jock, when ye hae naething else to do, ye may be ave sticking in a tree; it will be growing, Jock, when ye 're sleeping."

Sir Walter Scott, in The Heart of Midlothian

\section{Commercial Propagators and Distributors}

\section{The Fancher Creek Nurseries}

GEO. C. ROEDING, President and Manager

Fresno, Fresno County, California, U. S. A 


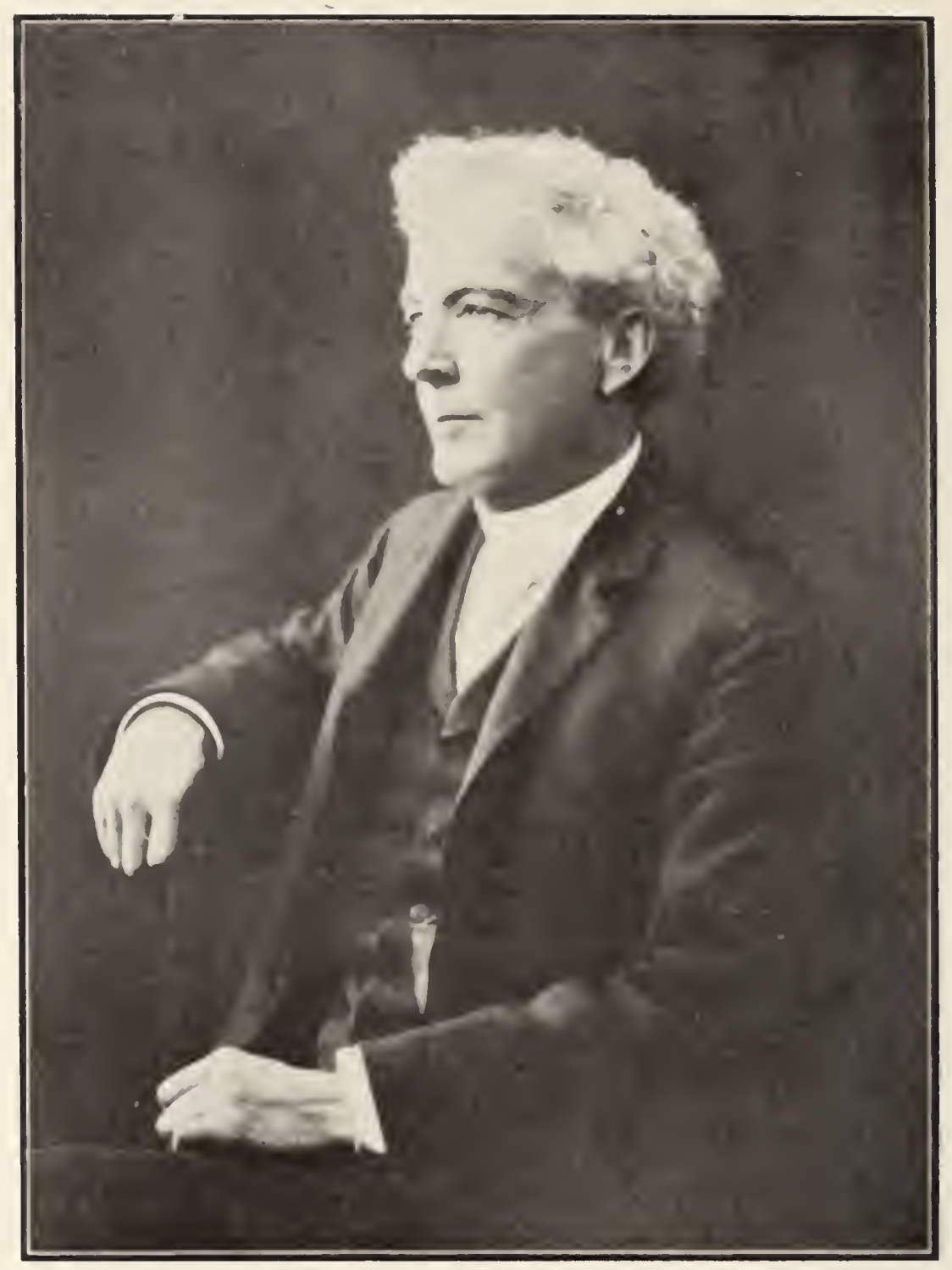

"Yours for better products and more of them" LUTHER BURBANK 


\section{THE REWARD OF MERIT}

CO PRONOUNCED has been the success of the new fruits and trees of Luther Burbank which we introduced for the first time last season; so appreciative have been the many warm encomiums from expert pomologists, commercial growers and amateur horticulturists on the Santa Rosa Plum, the Rutland Plumcot, the Royal and Paradox Walnuts, that we feel sufficiently encouraged to give place to three new plums of surpassing merit of Mr. Burbank's creation, viz.: the Formosa, Gaviota and Vesuvius. These have, for the most part, undergone a rigid test on his experimental grounds, with the result that they have been found to possess merit of the first order, and are being offered with the firm conviction that they will prove valuable acquisitions to the fruit interests of the country.

It is in a broad practical way, and purely on economic grounds, that Iuther Burbank has spent his life in the creation and exploitation of new things in fruits, flowers and plants. By nature his is the creative faculty, - the trend of mind that conceives, creates, executes in the realm of plant life. This being true and his work becoming so vast, it is not at all surprising that he should leave to others the work of "bringing out" his creations to the trade. Appreciating this his friends have long contended that he should be relieved of this phase of the business, so as to afford wider scope for his scientific and experimental work.

In this connection, the Fancher Creek Nurseries were approached with a view to introducing the Burbank creations to the trade. Accordingly an arrangement covering a series of years has been entered into between Mr. Burbank and this establishment whereby we become the commercial propagators and distributors of new plants and fruits known to possess real values of the first rank that he may put out from now on. We say "values of the first order" advisedly, for we have too high a regard for the horticultural interests to place anything on the market of a meretricious character; an opinion that Mr. Burbank not only endorses, but insists must be carried out to the letter. Hence our descriptions will always be found conservative and to the point; the conditions of climate, and soils governing the habit of the new introductions will be found based on experience, lucid in expression, true to the facts, and conservative in their deductions.

With these preliminary statements, we take pleasure in issuing a second edition of this booklet describing Burbank's latest introductions, all of which possess real value to the horticulturists and plant lovers of the country, as demonstrated in the originator's grounds.

Their individual values, uses and characteristics are briefly but thoroughly described in the following pages.

GEORGE C. ROEDING;

LUTHER BURBANK 


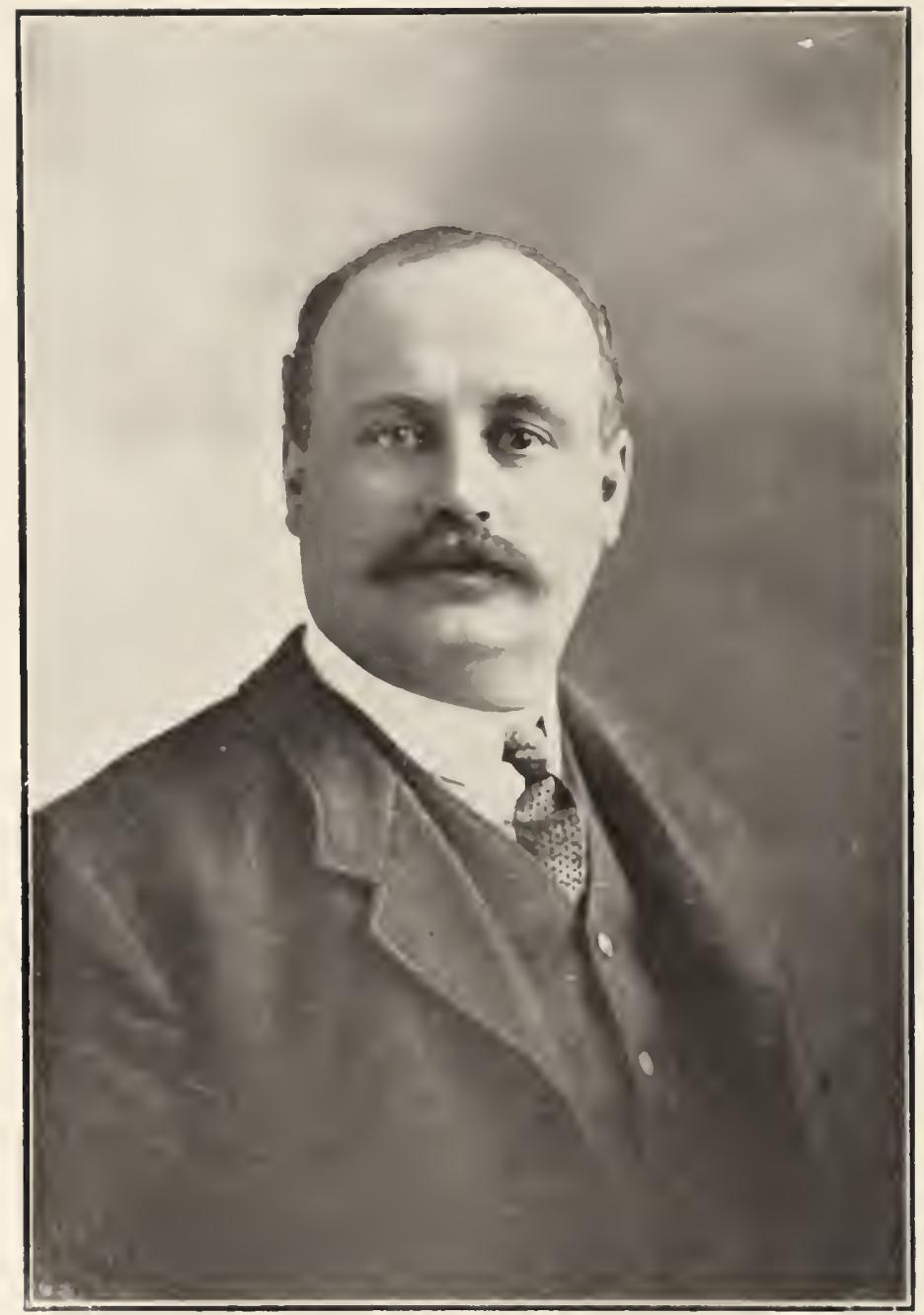

"New' and promising things should be tried" GEORGE C. ROEDING 


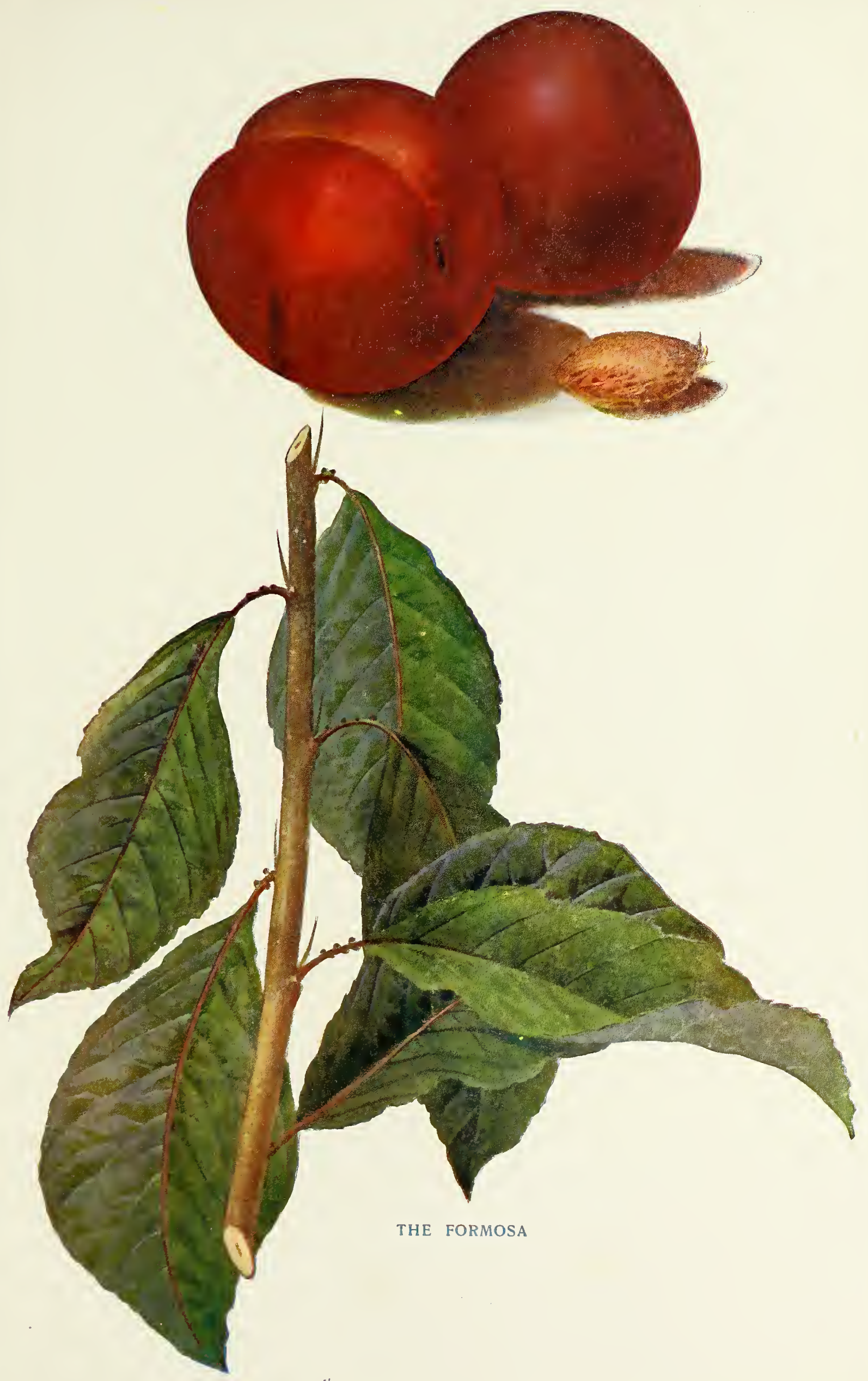





\section{A TRIO OF NEW PLUMS}

$\mathrm{T}^{\mathrm{H}}$

HE INTRODUCTION of a number of fruits, largely of the same character, is sure to cause more or less bewilderment on the part of the purchaser, and he is somewhat at a loss in making a choice. These latest creations of Mr. Burbank's all have merit, and have now been tested long enough so that there need be no question of their ultimate commercial value. We know it is a mistake on the part of the introducer to place any new fruit on the narket, unless he has sufficient assurance that such fruits as he recommends will stand the test of severe criticism when they reach the commercial grower. It is useless in these days to recommend a fruit of comparative merit, for unless the quality is actually in the fruit itself, the consumer, on whose judgment the grower must finally depend, would probably reject the new variety as not being equal to some of the old standards.

\section{THE FORMOSA}

See colored illustration by A. Lunzer, two-thirds natural size.

Formosa is an unusually handsome fruit which runs surprisingly uniform in size, in many respects resembling the fruit of the Kelsey and Wickson, but much more uniform and handsome in appearance than either. In flavor, firmness and coloring, it surpasses the older varieties in every sense of the work. It is said by Mr. Burbank to be of a rather mixed parentage, blending probably fifteen to eighteen varieties in its origin. Ripens about a week later than santa Rosa.

So high an authority as Prof. E. J. Wickson, author of "California Fruits and How to Grow Them," describes it as follows:

I have never seen this fruit before, an 1 I fin 1 it large (two and one-half inches longitudinal and two and one-fourth inches cross diameters) and handsome, red, shading from rather light to deep cherry color, the coloring being more even than the original Wickson as it grows with me. The variety also seems to have a tendency to greater symmetry, the heart-shape being less pronounced and the general exterior points of the fruit striking me as superior. Comnarison of flavor points could hardly be made unless one had the two varieties grown under exactly the same conditions.

In line with the above recognized authority on California pomology, Luther Burbank authenticates the opinions therein expressed:

This is a plun which has been very fully tested for the past five years in close conparison with all others, and has bcen pronounced the "best plum in existence" at the p esent time. The trees are wonderful growers (so far as known nothing comparable to Formos: is now in cultivation in this respect). with unusually large, thick, hcalthy, light green foliage; strong, hard, wiry wood, which is always capable of holding the great crops of fruit which the trees so far have never failed to hear. Even this year when all ordinary plums are either a partial or complete failure, Formosa is loaded with iruit of great sizc, unusual beauty, and unequaled in quality with perhaps the exception of the new Santa Rosa first introduced last season.

Formosa blooms with tlie Burbank and Abundance, and always escapes late spring frosts, and always bears profusely even when continuous rainy weather prevents full pollination in most other plums. No disease has ever found lodgment with Formosa. The fruit is of uniform size, a veraging about six inches in circumference one way by eight the other. Fruit yellow with a pale bloom until nealy ripe, turning to a clear rich red. Flesh pale yellow, unusualy firm, sweet, rich, delicious, with a delightful apricot flavor, nearly free-stone.

Formoca has been very thoroughly tested for its keeping qualities, which are unequaled except hy Santa Rosa, Wickson, Burbank, and a few others. 
Soils and Climates. - Formosa, like all the plum family, finds comgenial conditions over wide geographical areas. In view of this its trial culture can be recommended not only in the Pacifie states and Territories hut throughout the listern lniterl states, burope and of course all countries rnjoying a chmate similar to that of California.

In hahit of growth it is rather sprawting. henee the tree should be prumed quite severely when young and headed hack to binches from the surface of the ground. Plum trees are more or less subject to sun scald, whel is overome by having the branches start down to give ample shate to the hody of the tree. The first four seasons following planting, pratetically the same method of pruning as direeded for other fruits should be adopted. After the tree hase arequired its form and the main branches are sturly and strong (nough to support a crop). mutside of thiming and cutting out cross limbs. no further pruning is necessary. Experienerel growers have learned that the shortening proress of pruning, if

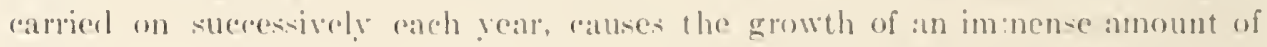
foung wood, which, although not strietly speaking suckers. nevertheless do not produce fruit. The fruit bearing hamehes assume at wepping tendeney, produce al large number of fruit hearing spurs, hut very little new wont. When it is notired that the tree no longer presents a heahthy appearance, and is also fating to bear profitable erops. veresere cutting hark will have to be resorted to in order to rehabilitate the tree to its former vigor. These remarkis refer more esperially. to California, and should le molified where clinatie conditions atre rallieally different, in whels atse the wise planter will be gruitle l by the pratice pursued bye experionsed plum grewers in his neighborhoosl.

\section{THE GAVIOTA}

See colored illustration ly .1. Lanzer, two-thorts natural saze.

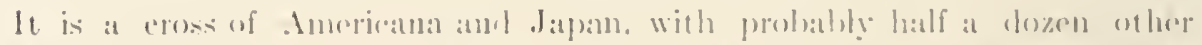
vaticties combined with it. This plum hats so many prints in its fator that we feel safo in recommending it are one of the very hest of the latest

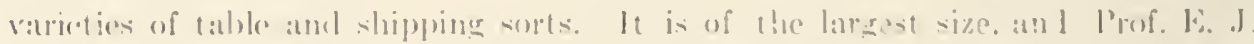
Wiekisul, acting director of the linted states Experiment station at Berke-

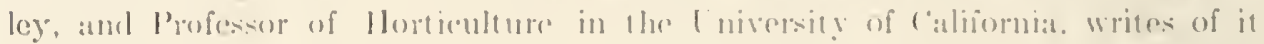
:L follows:

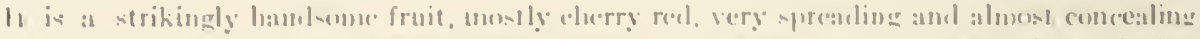

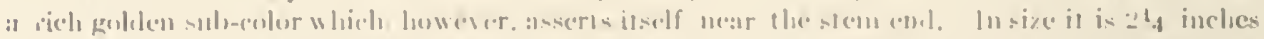

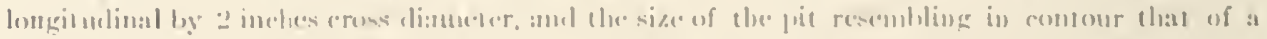

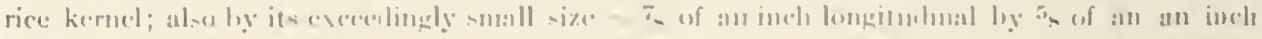

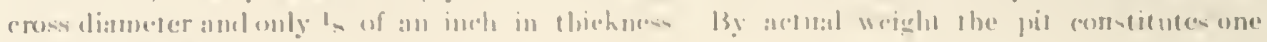

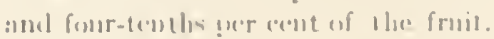

Irtually, llac pit is so smatl in comparion with time size of the fruit that

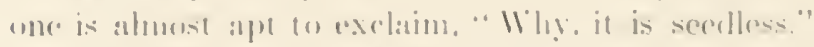

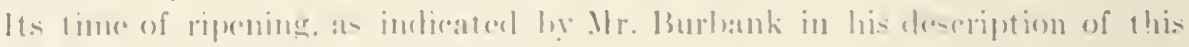

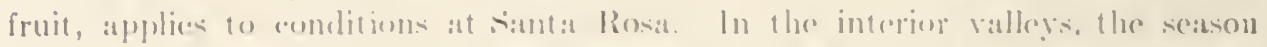

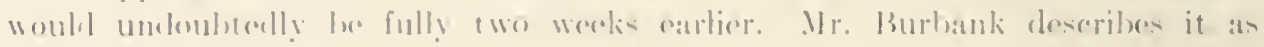
follows: 


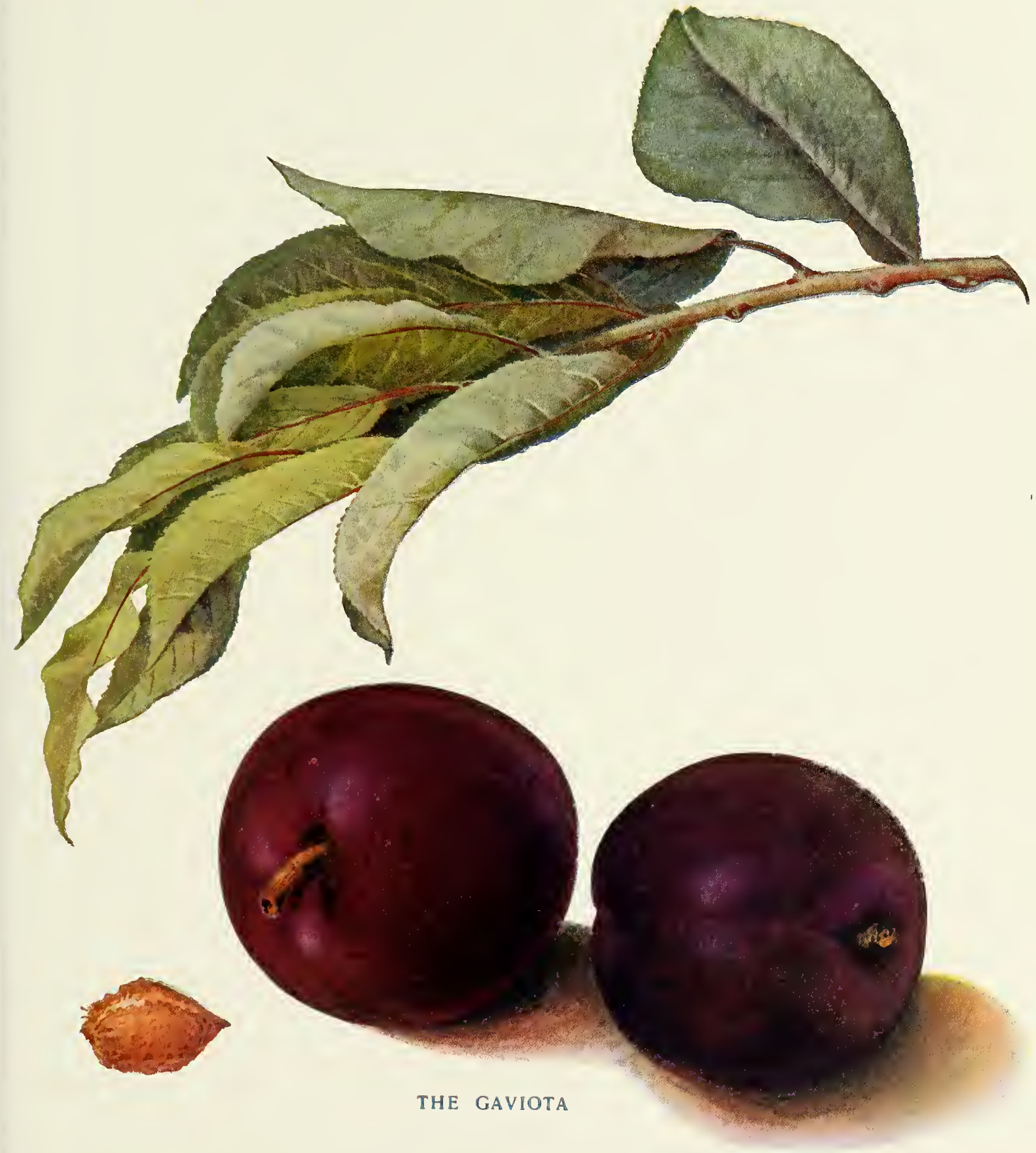



Ever since the summer of 1900 this superb hybrid shipping plum has been under carefu investigation on the experimental farm each season, and the trees have never failed to produce a good crop of fine large fruit. Neither the fruit or the trees have shown any disease or defect during all this test, and at the same time of this writing, July 25, 1907, are again loaded with large, beautiful fruit. While the trees do not make such a phenomenal growth as the Formosa, yet the few trees are more vigorous and productive. Gaviota trees are rather upright in growth until they have grown several successive crops, when the branches take a more weeping habit but not more so than other plum trees which bear so heavily.

Gaviota, is a late bloomer, hence always escapes every emergency, producing each season a full crop even when nearly all others fail from late spring frosts or rains during the blooming period. The fruit is of a deep reddish purple when ripe. Flesh remarkably firm, honey yellow, very fragrant and sweet and of excellent quality.

One of the very best shipping plums, keeping fully as well as the always popular Wickson and Burbank and ripening up well a week or more after being picked green. Its season here is July 15 to August 5, with the Wickson, and just after Santa Rosa. This thoroughly tested variety will take its place as one of the best shipping plums.

Distribution and Soils.-The Plum being among the hardiest of the stone fruits, it stands the reason that the Gaviota will grow in a climate where zero weather prevails, requiring in the more colder regions some protection during the winter months. It succeeds best in a good loamy soil, with an open well drained sulsoil. In planting the ground should be well broken up by thorough plowing, and the holes dug sufficiently large to enable the surface roots to spread and grow. In a rich soil the growth is apt to be vigorous, requiring severe pruning much like our suggestions with the Formosa. In training standards and half standards are generally favored in the colder regions, low pruning is the most recognized method in California. In planting we always advise that the general system and care bestowed on the most successful plum orchards in a given locality be duly observed and followed.

\title{
THE VESUVIUS
}

\author{
See colored illustration by A. Lunzer, one-half natural size.
}

The tree is worthy of its name, for its color is so surpassingly beautiful that while it excites admiration at a distance, closer examination only intensifies the first expression of delight which its beautiful foliage is sure to arouse. It is somewhat like Prunus pissardi, Purple-Leaved Plum, but so superior that it is safe to say, that the old purple-leaved plum will become obsolete. Its fruit is of a deep rich color, possessed of a pleasant acir flavor. It is not a very prolific bearer, hence we recommend it as a striking foliage tree worthy of a place in every garden and park. We give Mr. Burbank's description and do not believe that we can add anything further except to say that we endorse all his statements excepting that he does not do full justice to this most beautiful foliage tree:

The Prunus pissardi, a crimson-leaved form of the Prunus myrcbalana introduced twenty years ago, is the only good purple-leaved plum generally known. For the past eighteen years have been raising hybrids of this and the Americana and Japan plums, hundreds of which are 


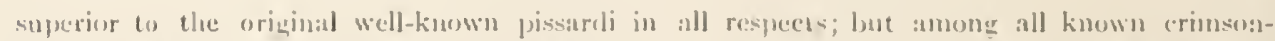

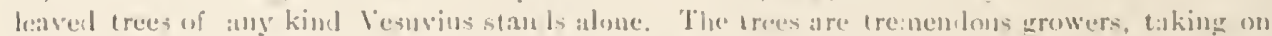

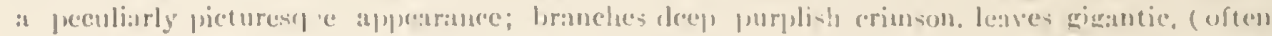

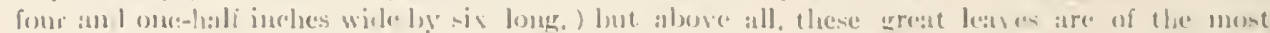

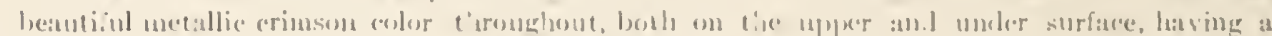

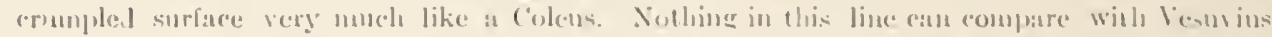

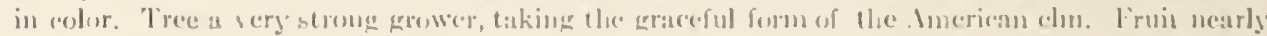

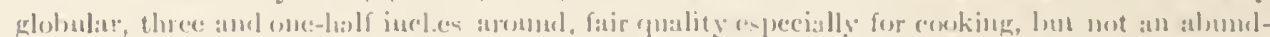

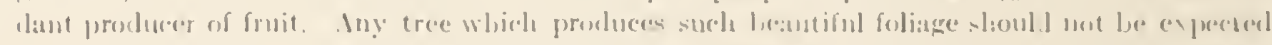

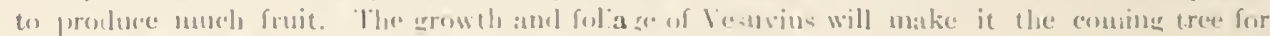

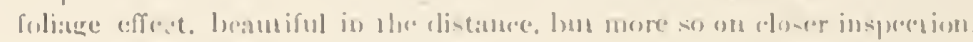

Planting and Treatment. Jothiner we call sal -o forribly illustrates tles

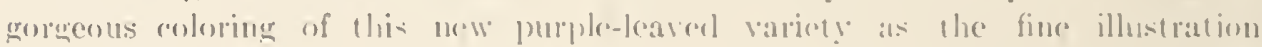

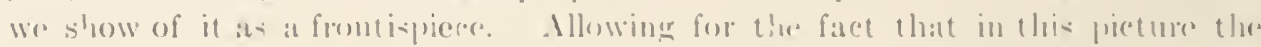

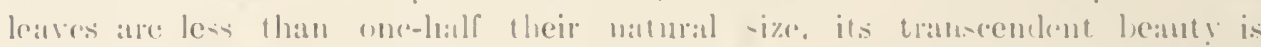

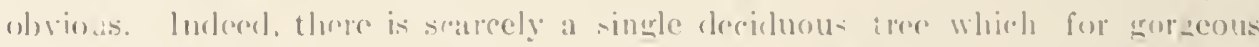

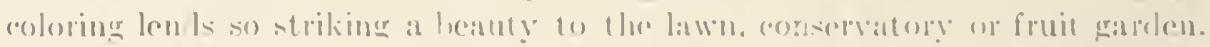

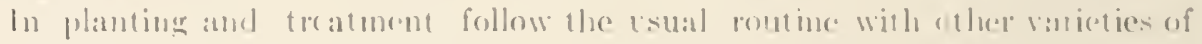

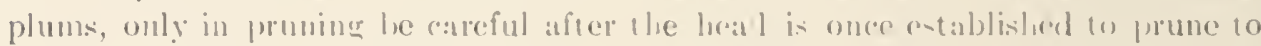

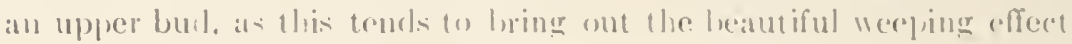

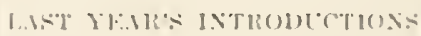

\section{THE SANTA ROSA}

sue culored illustrution hy A. Lunzer, Hatural size.

No one fruit has so stmonly individualized the name of lather liurbank as the plum. Fome half a dozen rarieties. now well known, are the result of his creative genius. all of which hate stoml the test of experience and in the markets of the worlt. As a matural result his latest, the sinta losa, is in erery way not conly a superior fruit from every point of view, but must be regarded th the best thing in the way of plums that hats come from his hands. It has been under trial on his fine experimental grounds at rebastopol for the past sevon years, during which time it has never failed to produce bounterus coros of uniformly large perfect fruits of a decp purplish-crimson color averaging six inches in cireumference cach way. It posesses every essential to a marked degree calculated to make it at prime favorite amoner inowers wherever the plum luxuriates, viz; is a grood grower, grood bearere, fine shipper, good leeper, and in erery way a moneymaker. No plum grower ean affort on negleet it, and no family ordiard should be without a frow trees.

At the Lewis and ('lark World's Fair, held at Portland, Oregon, 101905 ,

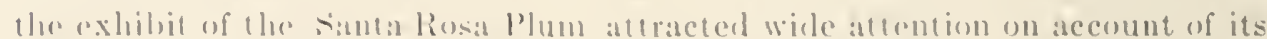
beanty and great sime. Indeed, its merit mate so stomg an appeal 10 the

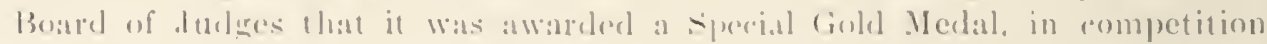

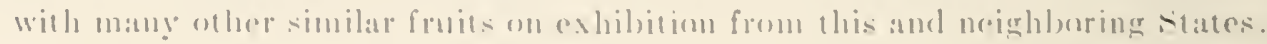

Distribution, Climates and soils. Like all kimeled plums it is safe to say

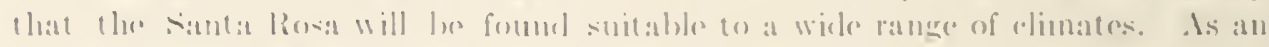

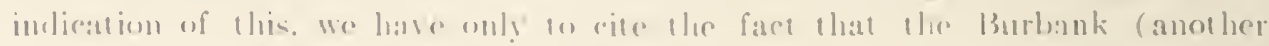




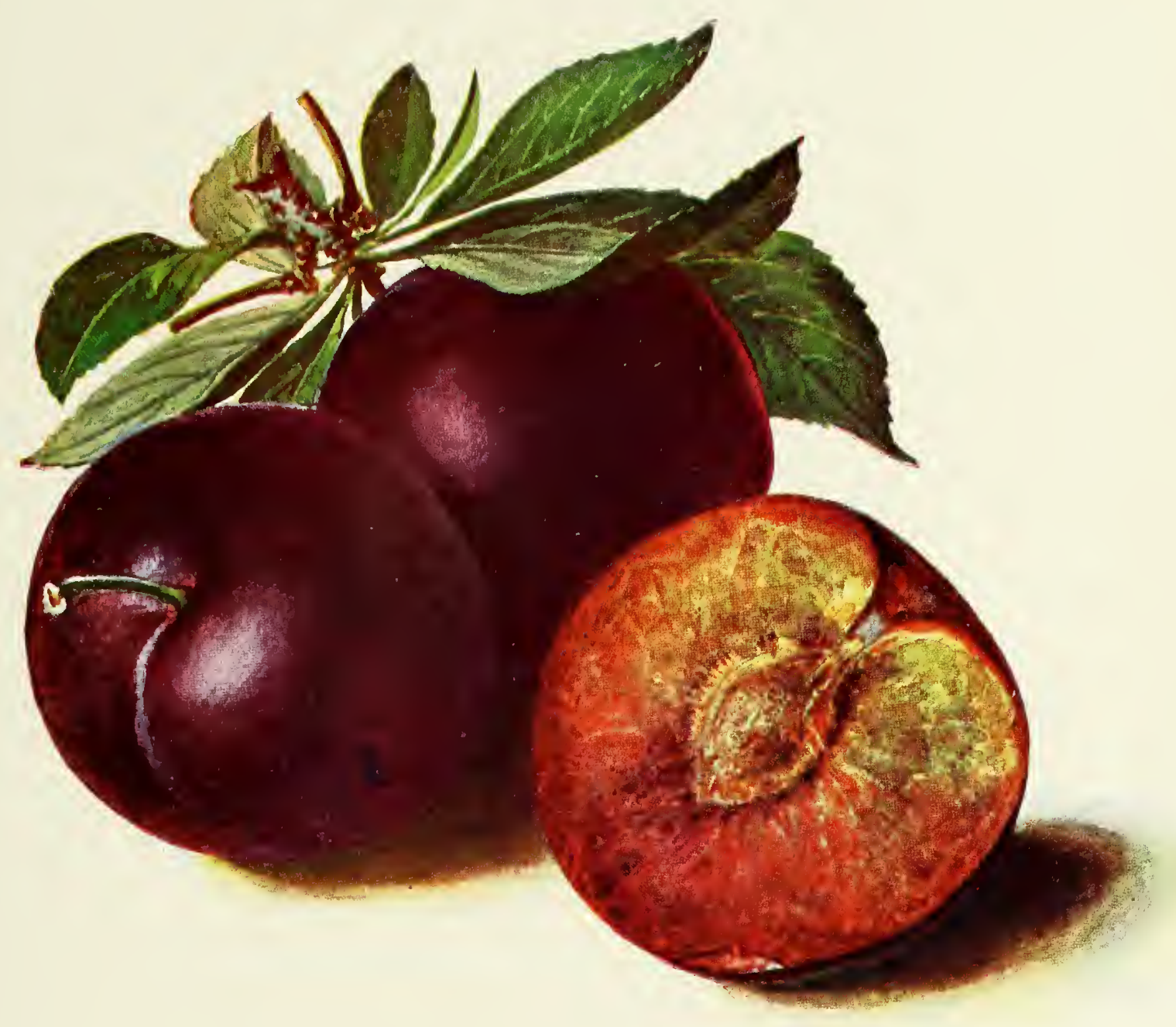

THE SANTA ROSA PLUM 

of Mr. Burbank's discoveries ) has found a congenial existence in so cold a climate as Minnesota and portions of Canada, which leads us to believe that the "Santa Rosa" is destined to win a place equally advantageous. Hence it is well worthy of trial culture wherever plums are found to grow and produce fruit. To do its best it should have a well drained sandy or loamy soil, and be given intensive culture. As to general treatment, that is much a matter of location, which will suggest itself by the general practice with plum trees under prevailing local conditions.

Blooming and Fruiting. The Santa Rosa plum in California is considered a medium early bloomer, and it is presumed it will maintain this characteristic quite generally wherever planted. In this state it has never failed to yield an abundant crop, though obviously, it is as yet but sparingly introduced.

Quality and Value of Fruit. The superb market quality of the Santa Rosa plum has never been equaled. As a shipping fruit it is the peer of them all,"standing up" under the most trying conditions. The plums are a deep purplish crimson with a pale blue bloom, each fruit averaging six inches in circumference each way; the flesh near the skin is purple shaded with rosy scarlet and pale amber towards the stone, which is quite small; the eating quality is unequaled, rich, fragrant, delicious, surpassingly exquisite; ripens with the earliest, nearly a week before Climax and Red June, and two weeks earlier than the Burbank. The Santa Rosa has been so thoroughly tested that we feel certain that every grower who will plant and care for the trees properly, and whose soil and climate afford good plum conditions, will, if he plants this grand plum, find that we have not exaggerated its fine qualities.

Habit of Growth. The tree is a strong, vigorous, upright grower. In liabit it much resembles the ever popular Wickson with even larger and more abundant foliage, thus affording ample protection to the fruit. The period after planting at which it will bear depends on prevailing conditions of soil and climate. It is Mr. Burbank's experience that in favorable situations it will yield fifty pounds of fruit when the trees are four years of age; this will of course be more or less modined by the character of the soil, elimate, care and cultivation given an nrehard.

Judge S. F. Lieb of San Jose, a prominent grower and a recognized authority on fruit culture, has given this plum a thorough test, and writes as follows touching on its many admirable qualities:

Fancher Creek Nurseries, Fresno, Cal.,

San Jose, Cal., October 10, 1906.

Gentlemen :- Your favor of the 29th at hand. I have had the Santa Rosa plum fruiting in an experimental way for four or five years; I have therefore tested it out very thoroughly. Everything considered, I am of the opinion that it is by all od ds the finest all around plum Mr. Burbank has yet produced, and I have kept close track of all of them. It is a fine grower, the wood is very tough and the limbs will not break. It is a sure and regular bearer and bears always most abundantly. It does not have any off years. The fruit runs remarkably fine, even in size and astonishingly smooth and clear of any def :cts. It is beautiful, delicious ind a very fine carrier to Eastern markets. It will keep well in hot weather for a week after it is ripe, so thers is no occission to pick it half ripe in order to ship.

I intend to plant it very largely myself, and to the exclusion of all other shipping plums.

"This grand plum has been so thoroughly tested," writes Mr. Burbank, "that we offer it as above, knowing that all will be pleased with it." 


\section{THE PLUMCOT}

see cole resl illuaralion l,y 1. 1,unzer, natural mize.

As its llane relearly indicates, this new eantinlate for horticultural homors, is a

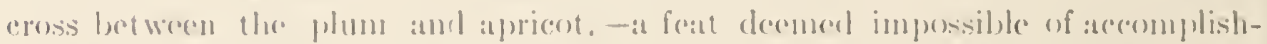

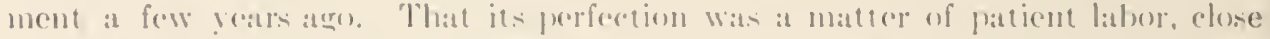

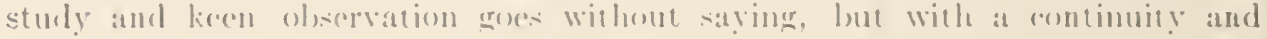

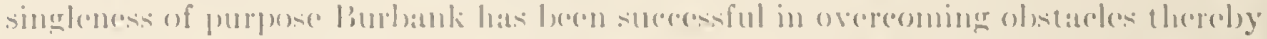
creating a fruit which happily partakes of the gualities of both parent stocks.

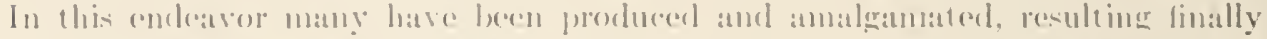

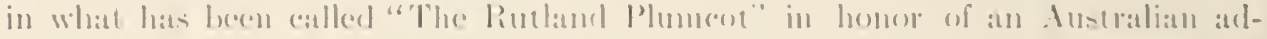

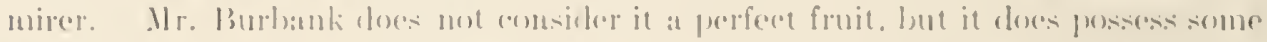
strong points of epecial interest to fruit growers. For instancere though not at

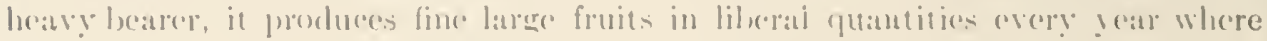
aprients fail, thus to at ereat estent increasing the area for that fruit.

Distribution, Soils and Climate. liy reason of its barentatere, the liutland

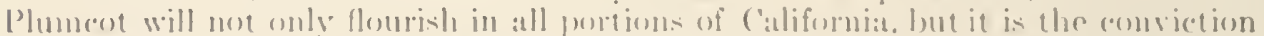

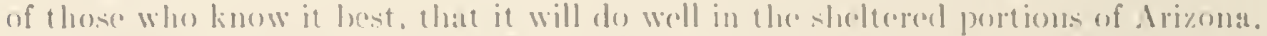

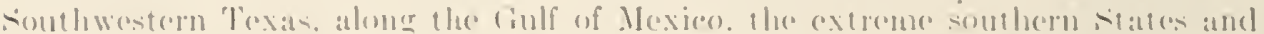

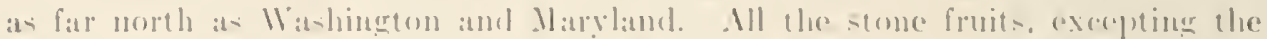

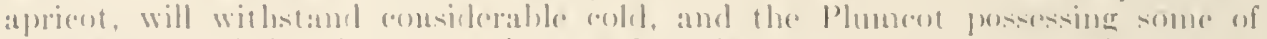

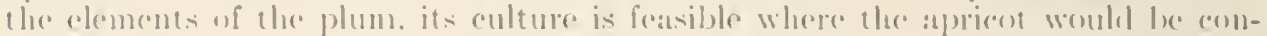

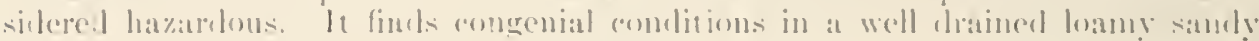
soil, and is kerenly responsive to intensive culture.

Blooming and Fruiting. Though reerentized as an early hooner, it never-

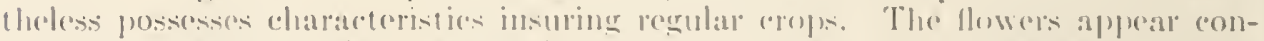

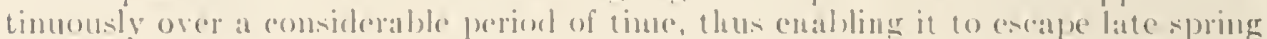

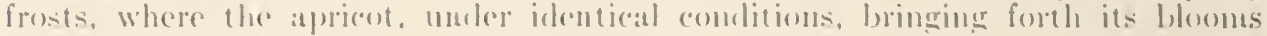
all at one time, suffers a total loss of its (rop). This of itself is at intportant feature in its fatror, especeially in locialities quite sulpject to spring frosts.

- Charazter and Value of its Fruit. ()bviously the andalgumation of the apricot

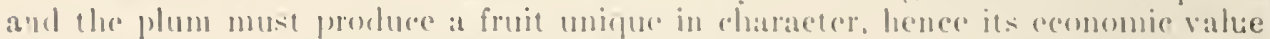

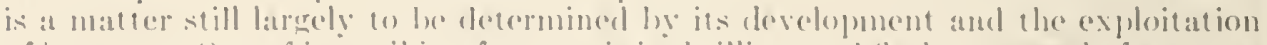
of its uses. One of its striking features is its brilliant red flesh possesserl of a strong

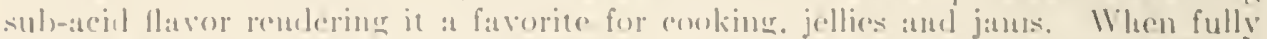

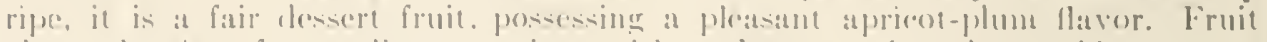
about the sizo of an oretinary atpricot with a derep purple velvery skin.

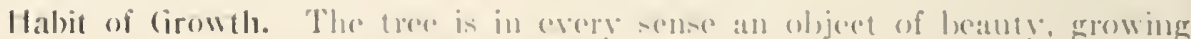
much like a wereping willow with long proululous loranches which hend and hang

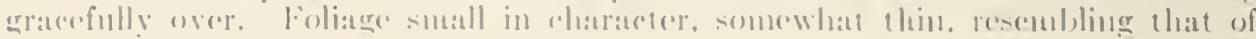
the phum rather that that of the aprient.

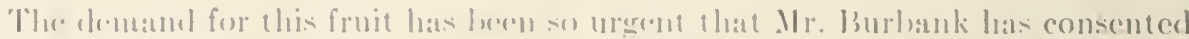

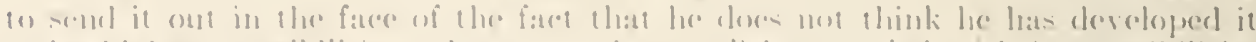

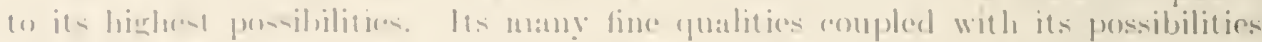

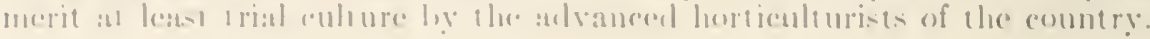




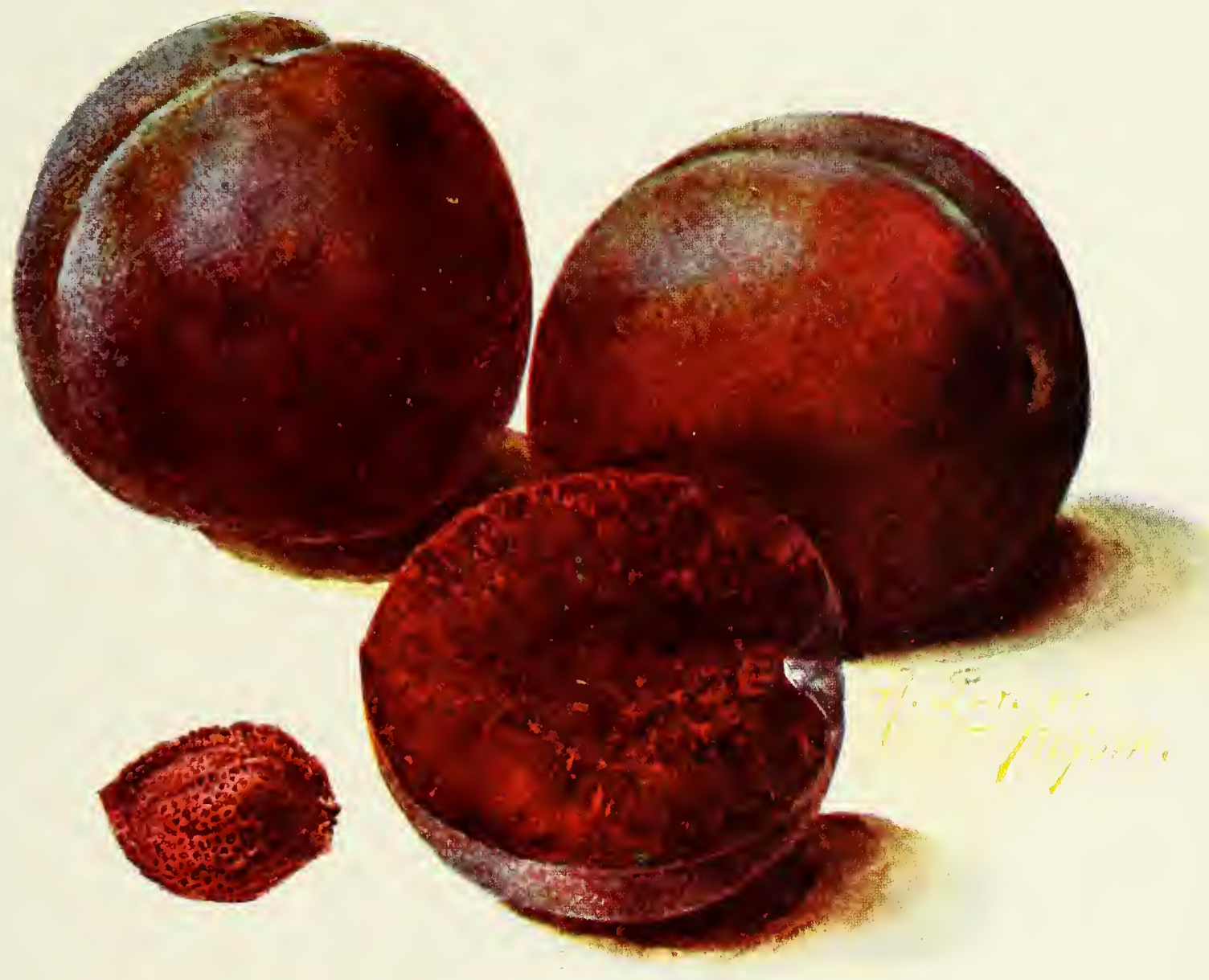

THE RUtLand Plumcot 



\section{A LUMBER, FUEL AND SHADE TREE \\ RAPID GROWING. FINE SHAPE. DENSE WOOD. \\ THE NEW HYBRID WALNUT, THE PARADOX

\author{
Juglans Californica $\times$ Juglans Regia.
}

$\mathrm{T}^{\prime}$

HERE has been a demand in California, and for that matter wherever the Eucalypts flourish, for a rapid growing deciduous tree for fuel and lumber purposes, street and avenue planting, and wherever immediate tree growth is demanded. The Blue Gum (Eucalyptus globulus) among evergreen trees will always hold its own; but where a deciduous tree is desired this new hybrid walnut is destined to occupy first place. In rapidity of growth it is suggestive of such quick-growing treas as the Blue Gum, distancing all other nut trees in rapidity of growth, size of foliage and beauty of form. Budded trees six years of age under the same conditions are fully twice as large, broad and tall as Black Walnut trees at ten, or Persian walnut trees at fifteen years of age. Twelve to sixteen feet growth in the nursery rows the first years is not unusual: thus the hybrid grows twice as fast as the combined growth of both its parents. The leaves, which are from two feet to a full yard in length, are clean cut, glossy, bright green, have a surpassing sweet odor resembling that of fragrant apples and as powerful and peculiar as that of roses and lilies.

The bark is thin, smooth, light gray with marblings of white; the wood is very compact, with lustrous silky grain, taking a beautiful polish, and as the annual layers of growth are an inch or more in thickness and the medullary rays prominent the effect is unique. This hybrid originated in 1885 from a cross made the year before; like many true hybrids, though blossoming freely every season, it seldom bears nuts and is readily budded or grafted on thrifty young Black Walnut stock. As an ornamental tree it is peerless and for wood and lumber possesses merit out of the ordinary. In shape and habit of growth it is very pleasing to the eye. rendering it especially desirable for ornamental purposes. As is wellknown, the evergreens (if too plenty immediately surrouuding houses and gardens ) are quite apt to intensify a sense of gloom and chilliness during our rainy season, because shutting out sunshine to the house or surrounding vegetation at a time when it is usually welcome. In planting the Paradox Walnut this is largely overcome, and the beauty of the landscape enhanced during the winter by its absence of foliage and likewise in summer affording a comforting protection from the hot sun by its presence. Its nuts possess little commercial value.

\section{QUICK -GROWING STREET AND AVENUE TREE}

The illustrations of this fine specimen are views of the tree from which our measurements have been made. This tree is growing on the street corner of Mr. Burbank's historical home. His commodious new louse was almost completed when the view was taken of the tree in foliage and is seen directly across the street. For avenue purposes there are few trees superior to this exceedingly rapid 
growing walnut. The writer lats seen trees of the Callifornia B Back Walnut and Paradox five gears old. planted in orehard form, ancl the l'aratox was fully ten inches in dianeter, while the California B Back. taking the very hest tree for comparison, did not measure over seren inches. leaving out its value, which is unquestioned for timber, atrenue and stree planting. the fact that it is such a rematrab) strong grower makes it addlitionally valuable to serve ats at stocts for grafting. Another point, which should be horme in unind is that the Ferenele and

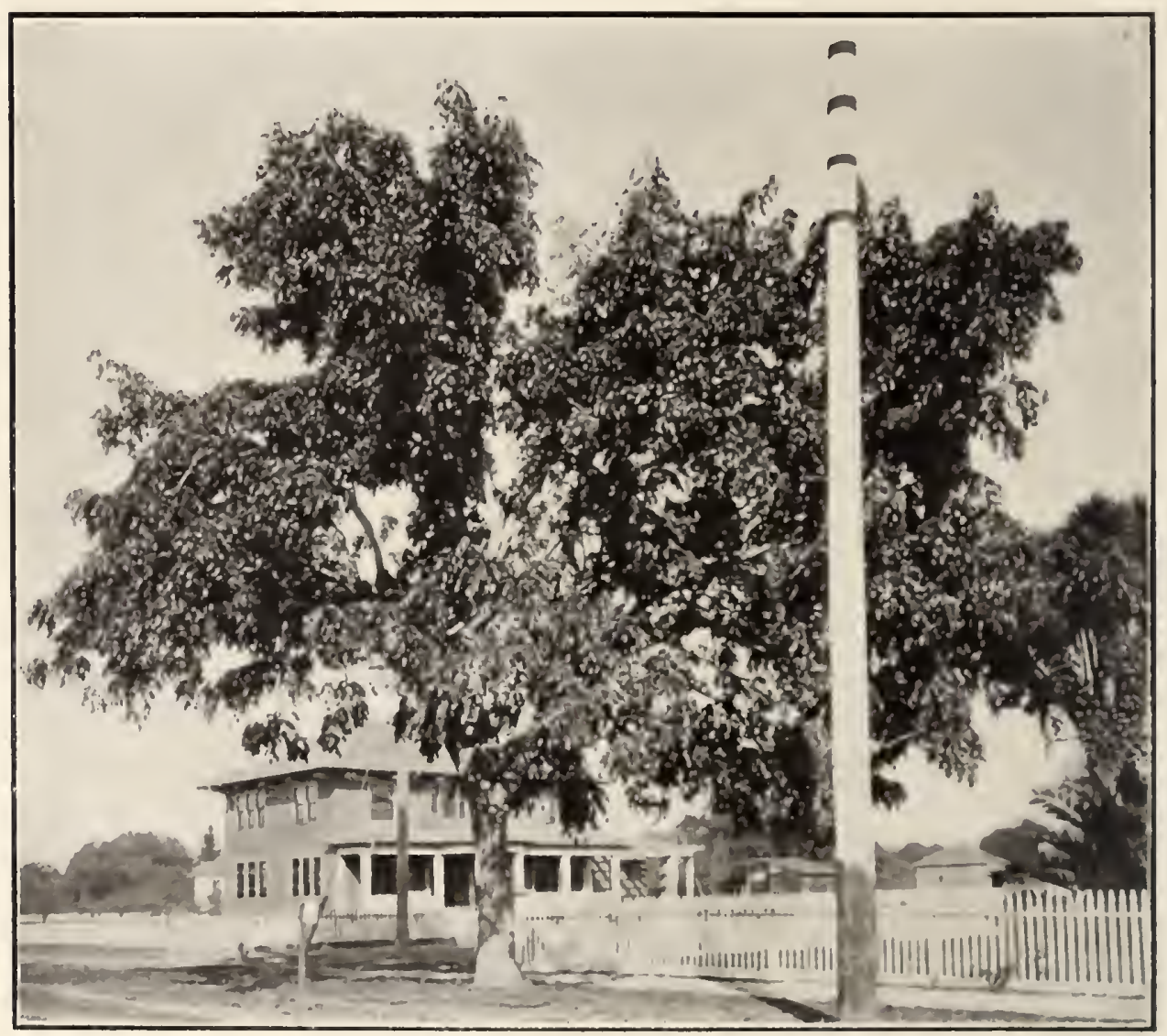

The Paradox Walnut Tree in foliage.

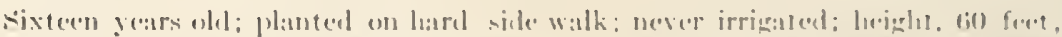

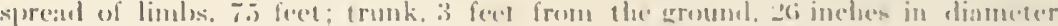

Enerlish wahuts have at erreater aflinity for this sterek than they have for the cali-

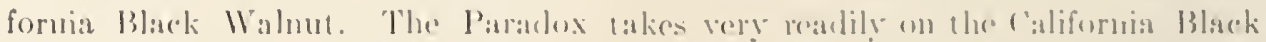

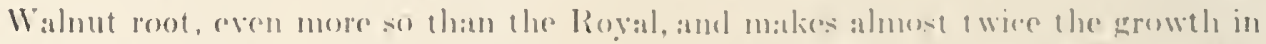
the nursery rows. In grafting Paralox in mursery rows on (alifurnia Black Walnut, no differulty is experieneed in secenting aseventy-five per cent - sand.

Adaptability. The french 11 alnuts find congenial comlitions at Interlaken, switzerland, at the have of th. Junefrat in the swis. M/ps, where it is 
intensely cold in the winter months. The writer has seen these trees, and they are hundreds of years old and are in the thriftiest condition. It is of historical interest to record that during the Revolutionary war George Washington camped in an English walnut grove situated within what is now a portion of Greater New York City. This historical grove bore nuts during its existence, which only

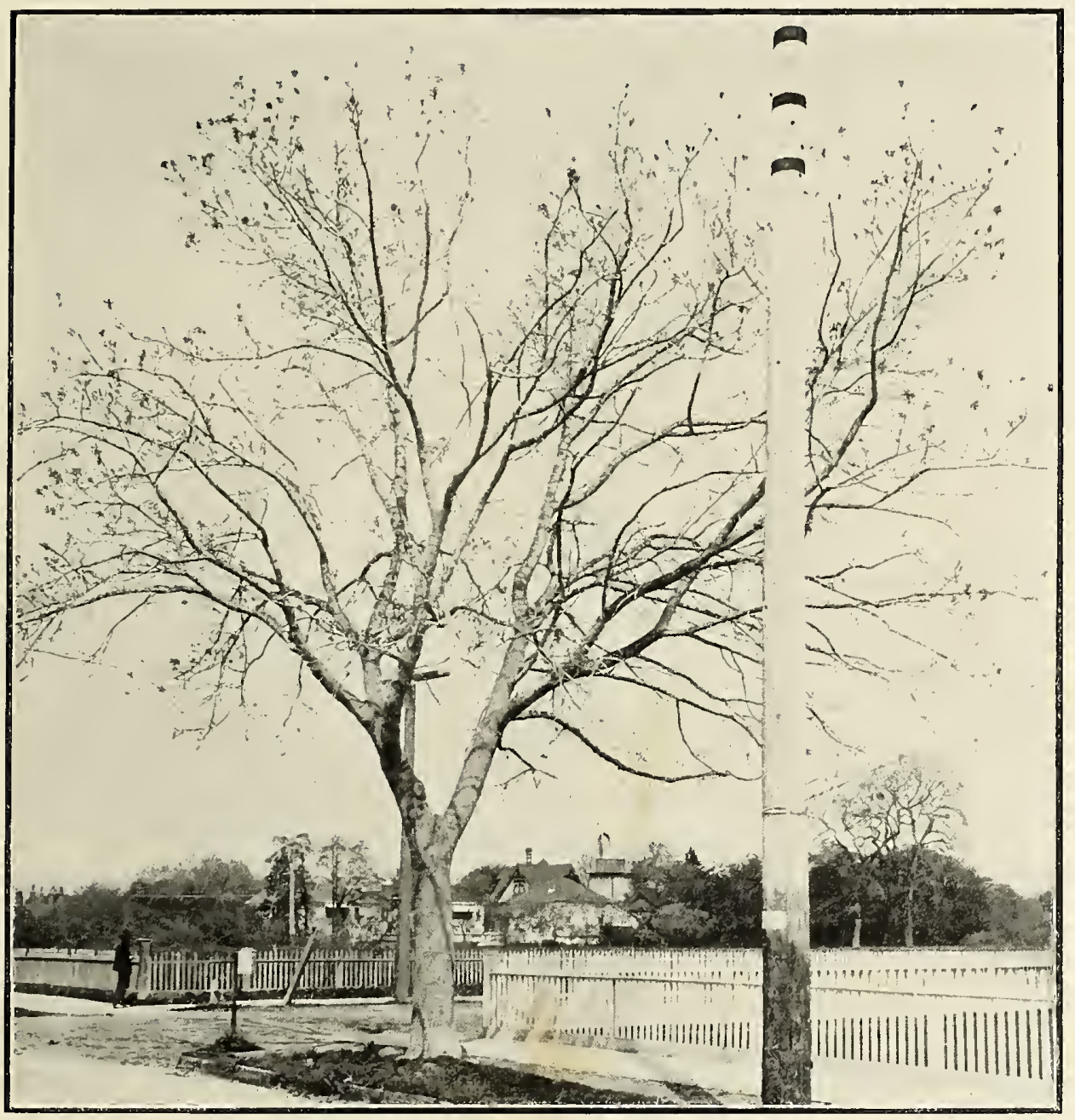

The Paradox Walnut Tree dormant.

ended some twenty years ago, when the land was required for building purposes; clearly indicating its wide and diverse geographical distribution and its capability of luxuriating in a cold climate. Indeed, the common English and so-called French walnuts (which are practically alike) will thrive fairly well in Central New England, suffering from damage by biting cold only in the destruation of the tips of the branches. Large trees are found here and there which produce a few nuts occasionally. The very fact that the 
English Walnut is hatrdy in Interlaken is suffieient evidenee that the l'aradox. which is a cross leetween the linglish and Califomia Black, will find conditions throughout the castorn and western states. Whele there are great extremes of cold

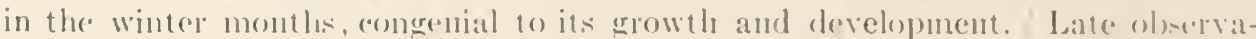

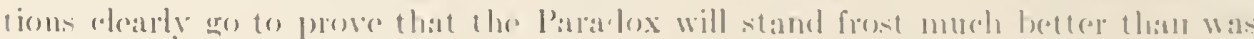

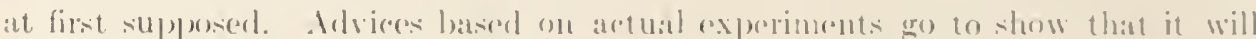

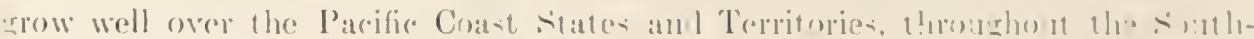

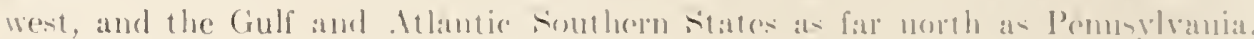
and possibly throughout most of the uretherm states.

Planting. 1) not fail to dig the hole in which the tree is to be sot, at least two feet in dianetre and two and one-halt feet deep, and loosen up the soil at leeply as possible in the bottom of the hole. When the tres is sict the collar should not be more than two inches below the surface of the enremule. The

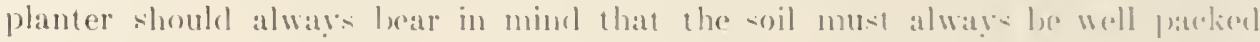
aromel the roots at the time of planting.

Winter Protection. For at leat two years after the trees are planted, they shoukl be wrapped with enoln stalks in localities where the winters are very severe. Rye straw would answer if corn stalles are not atrailable.

Vuts. For some unexplainable reason this varien never produces many muts and those that are problueed are retained by Mr. Burbank for planting with a view, by selection, of still further improving this tree.

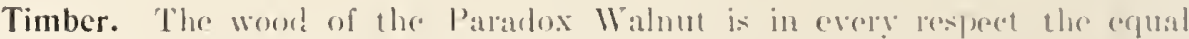

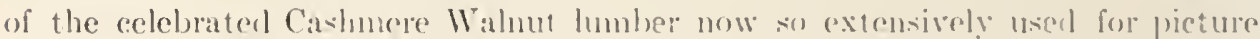
framing. It works up smoother and has a fincre compact erain than the ordi-

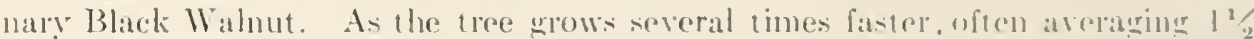
inches in diameter annually on good soil in Californial, it rertamly posseseses attractions to the timber grower. Its parent, the common kinglish Walnut, on rultivater grouml at simta Rosa, California, at thirty-three vears of atye, showed a total growth of nine (o) twolve inches in dianeter, while at only sixicen rears of age the l'aradox on a der. hard sidewalk is oxer twofeet in diancter at four feet from the ground. It is well to hest in mind that wahnut trees require some

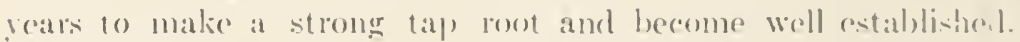

In view of these facts. it is pertinent to ask, what will be the size of l'arat dox trees whell thirty-three years of atro". W'ill ihey not be four times as great

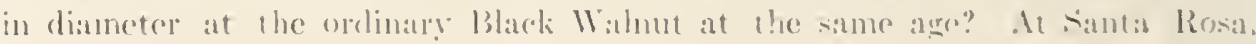

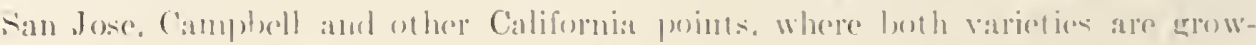

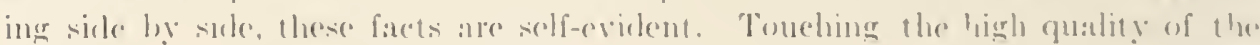

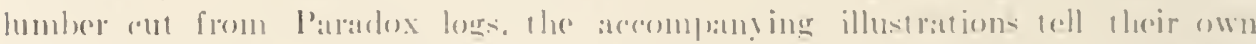

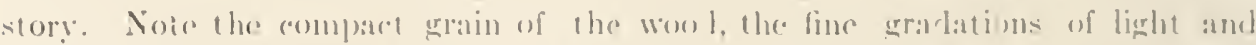

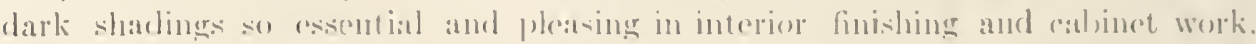

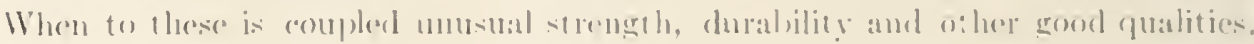

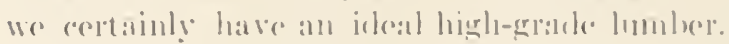




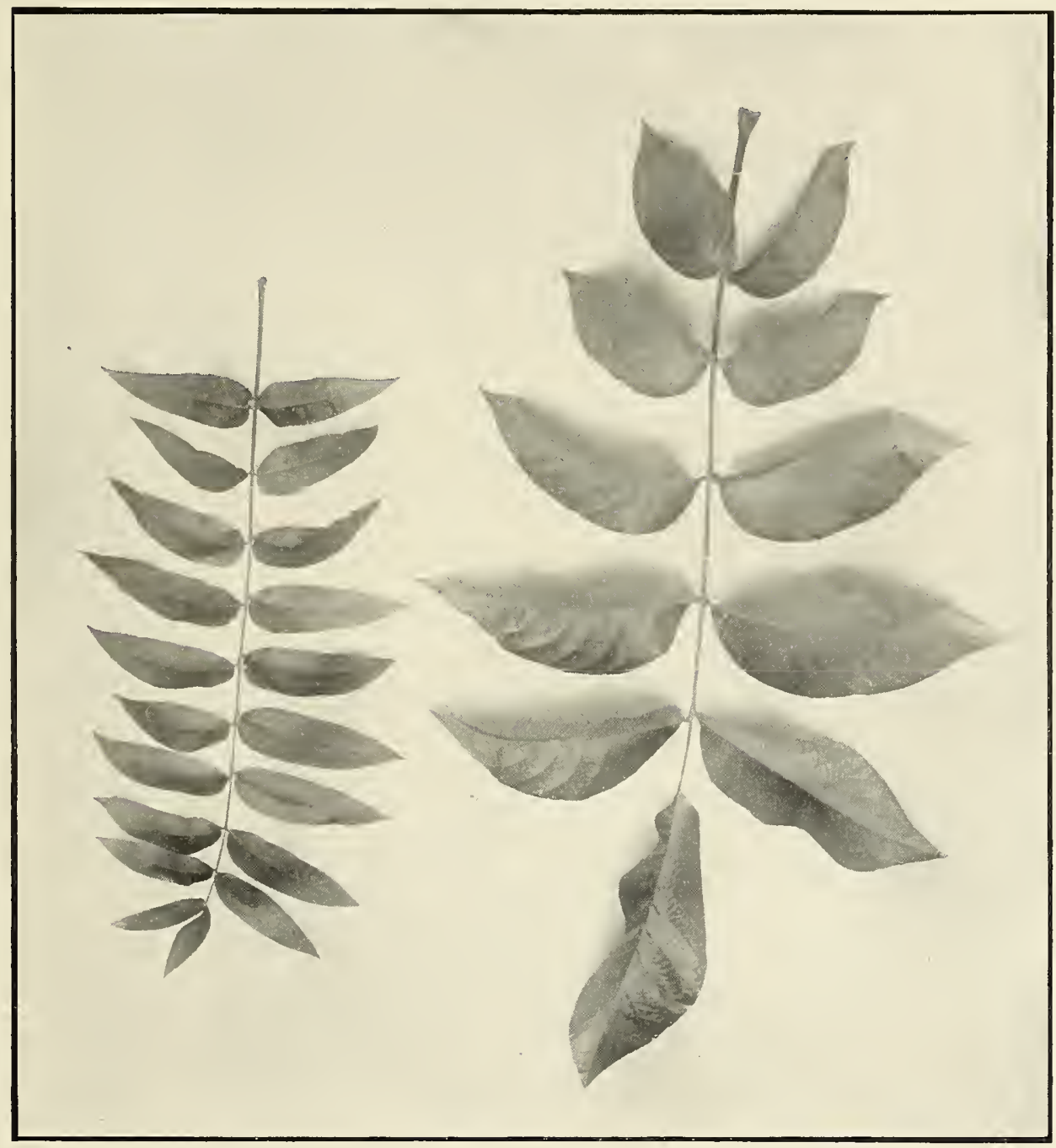

Foliage of Royal Hybrid

Foliage of the Paradox Walnut

\section{OFFICIAL RECOGNITION OF THE PARADOX}

In 1877 Luther Burbank crossed Juglans regia with pistillate flowers of J. Californica. Resultant nuts were planted in 1878 , and in ten years the tree from one made the remarkable growth of twelve inches in diameter at two feet from the ground. It was then accilentally destrryed. Buds that had pierirusly been secured and set on other stocks show the same luxuriant growth of wood and foliage. Tiees of these four years from bud, transplanted to a hard sidewalk, were in 1891 sair? to be as large as California trees ten vears of age; the leaves have a very strong, delightful fragrance of new apples, unlike any other tree. The bark is light colored, thin, and very smooth. Spcciren leaves nearly a yard in length, and a photograph of the budded tree, sent to the Division of Pomology in 1892, indicate that the tree is a shapely, symmetsical grower that furnishes abundant shade. Mr. Burbank says: "No other tree that I have seen, except Eucalyptus, will equal this in growth." This tree has not yet fruited. He has some crosses of J. nigra and J. Californica, of which one is six years old and exceedingly handsome.-[U.S. Department of Agriculture, 1896. 


\section{THE LUMBER TREE OF THE FUTURE}

THE NEW HYBRID

\section{THE ROYAL BLACK WALNUT \\ Juglans nigra $\times$ Juglans Californica.}

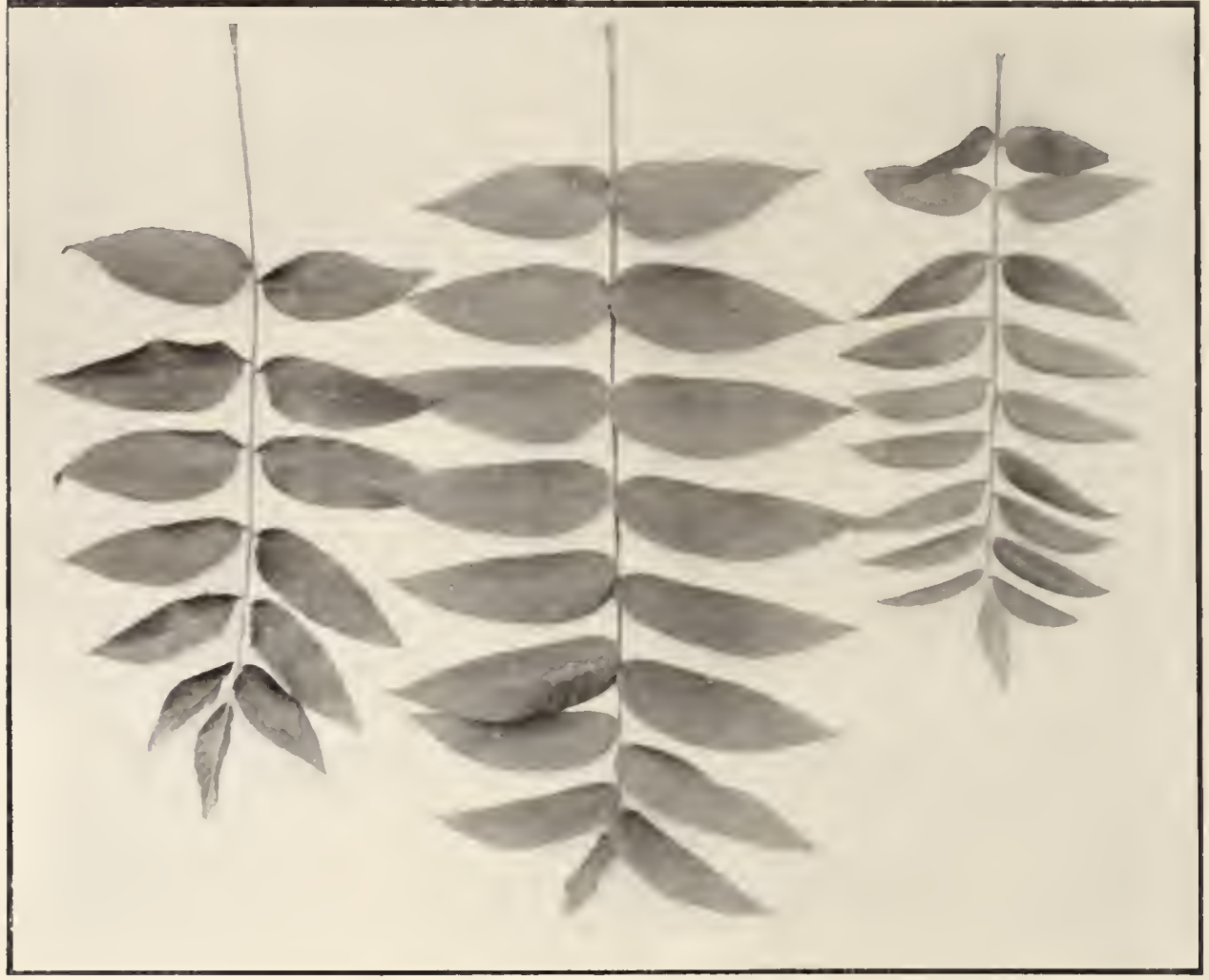

Eastern Black

Royal Hybrid

Cal. Nalive Black

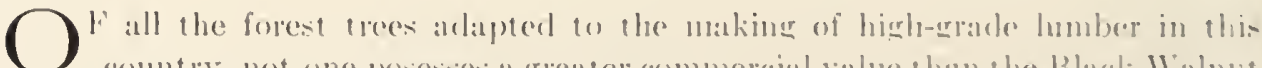

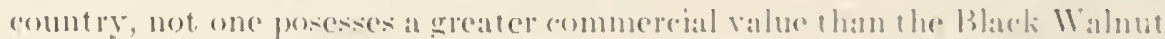

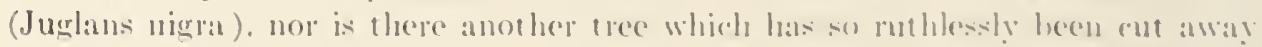
from the lamdseape of its mative habitat. The rich forestic of the mppor Mlississ-

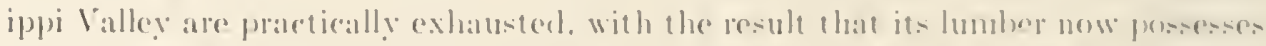

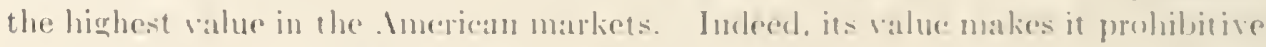
to a lane exerut for the puposes o which it was originally used in the manufareture of furniture and interiof lonse fonishing. The resulf is lhat it is now exernsively used as a veneer face to other and eheaper wookls. The tree is a sow grower. which fact has somewhat retarded reforestation and planting for purpuses of lumber. 


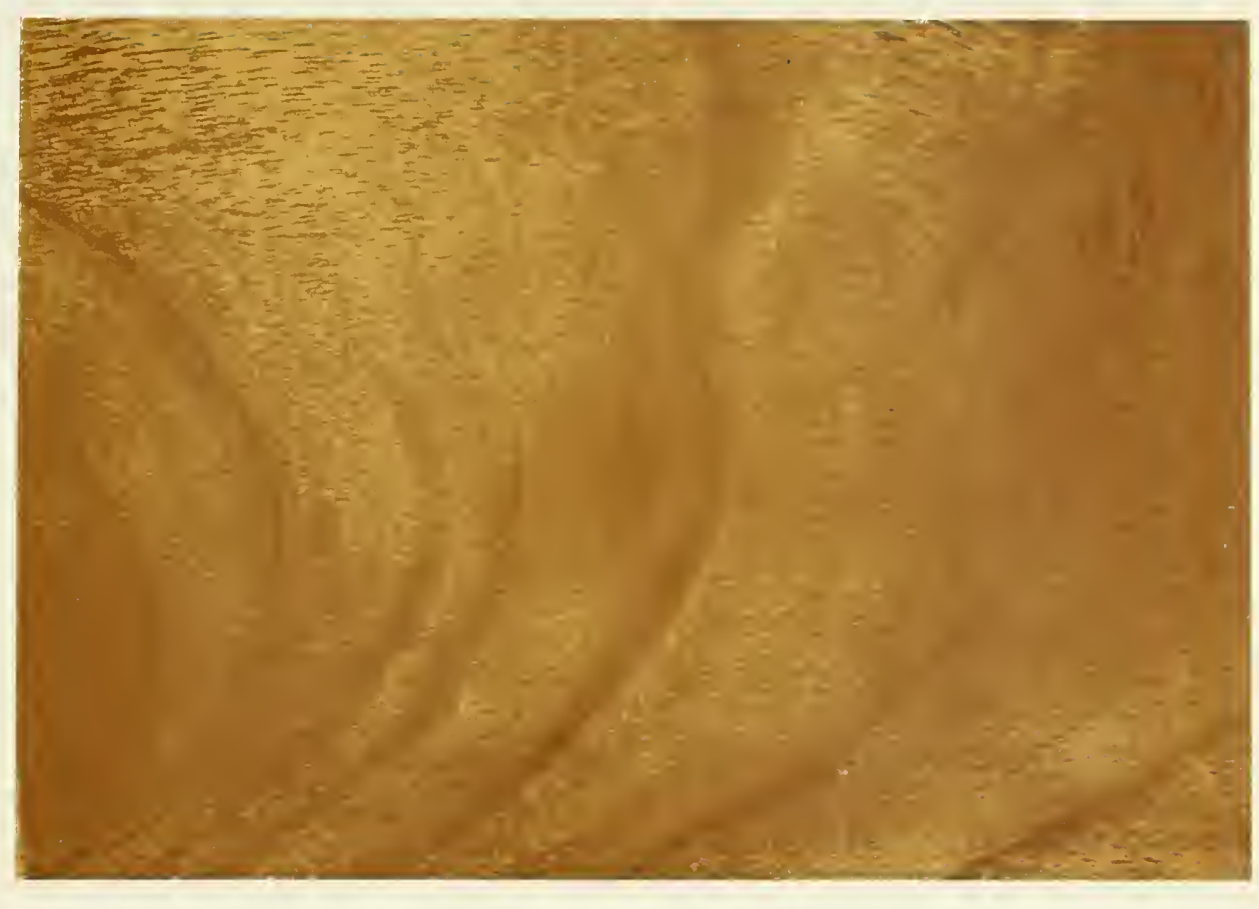

FINISHED LUMBER OF THE PARADOX WALNUT

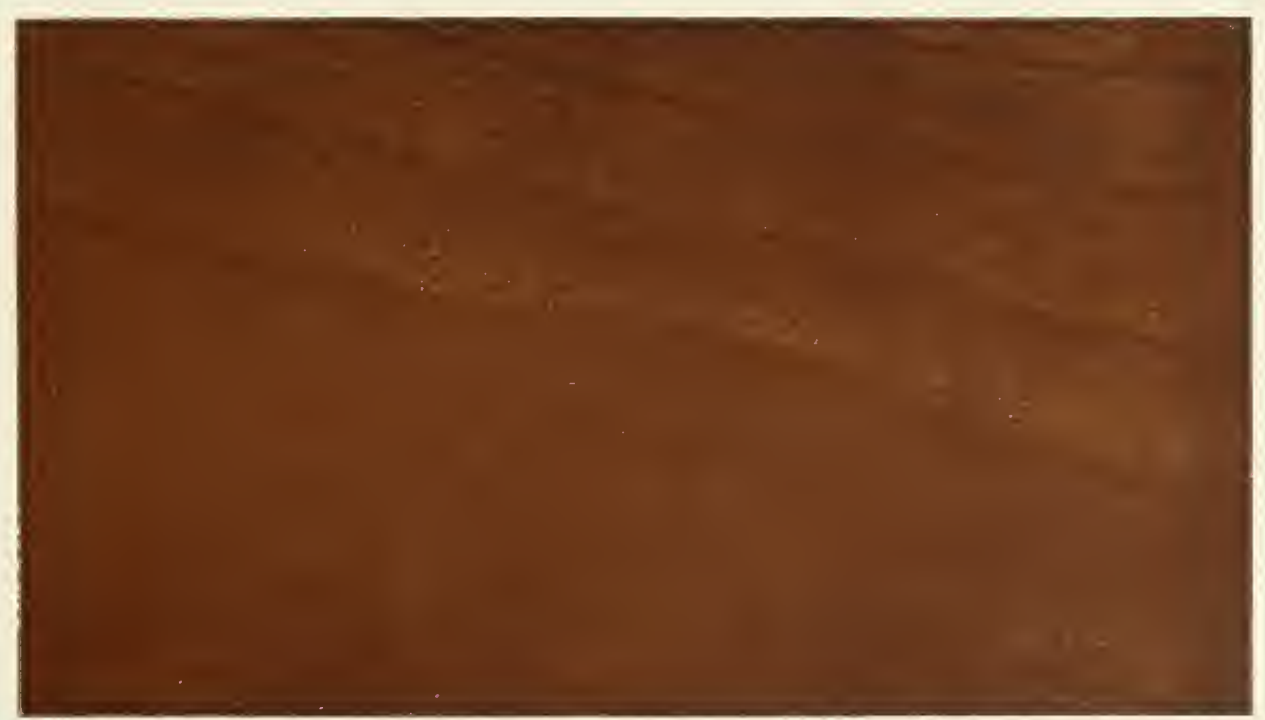

FINISHED LUMBER OF THE ROYAL BLACK WALNUT 
These considerations have become more pronounced as the native trees have become exhausted, and the feasibility of growing the Black Walnut for timber purposes has often been urged on land owners and foresters. The principal obstacle has been the rather slow growth of the tree, it requiring something more than twenty years to produce sawable $\log$ s. These conditions excited the mind of Mr. Burbank to the feasibility of hybridizing the Black Walnut (Juglans nigra) of the Mississippi valley with the California variety (J. Californica) with the hope that the hybrid would produce a wood of fine quality and a tree which for rapidity of growth would produce merchantable timber in half the time required by the Black Walnut,- a feat possible only by the patience, care, minute observation and "know how" of a Burbank. Hybridization in the wild state happens at very rare intervals, hence we believe that the Royal is the first case on record of its having been accomplished artificially.

It is the first hybrid of this kind ever brought to the attention of botanists and horticulturists. The original tree was produced in 1878 by crossing the American Black Walnut (Juglans nigra) and the California black walnut (J. Californica). The first year of its existence it outgrew all other trees in its vicinity and at the end of the first season was fully four times as large as the most rapid growers of its kind, while all the trees grafted from it have maintained this phenomenal development, holding its own with any other tree which can be grown in temperate climates. Unlike many hybrids these trees produce large nuts in the utmost profusion at an early age even while making such a wonderful growth. The nuts are larger and of much better quality than ordinary black walnuts but are not esteemed for food purposes. The value of this new creation is for lumber and fuel and incidentally as a shade and ornamental tree of great beauty and grand proportions. It has proven to be hardy wherever the common Black Walnut thrives. Practical lumbermen were at first in doubt if such a rapid growing tree could produce dark, hard, close grained wood of a silky fibre which would take a fine polish, but on trial the wood has been found to have all the best qualities of the ordinary black walnut lumber in perfection. The wood is exceedingly hard, close grained, takes a silky polish and is even superior to ordinary black walnut lumber, more nearly resembling the tropical mahogany.

The Royal makes such an unequaled growth that it will be best to plant the trees for timber growing about fifteen feet apart each way and when six to ten years of age half of the trees should be removed to give the remainder room. Cultivation during the first few years is of great advantage. Any ordinary crop can be grown among the trees until they claim the whole space.

Soil. The Royal as well as the Paradox will be found adapted to almost any good average soil: providing there is not a stratum of rock or hardpan close to the surface; and for that matter if proper care is taken to blast out the hardpan before planting, such soil will develop strong, thrifty trees. As might naturally be inferred, a deep, alluvial soil, moderately moist, will produce a larger, finer and thriftier tree in a shorter time than a soil not possessing these qualifications. 


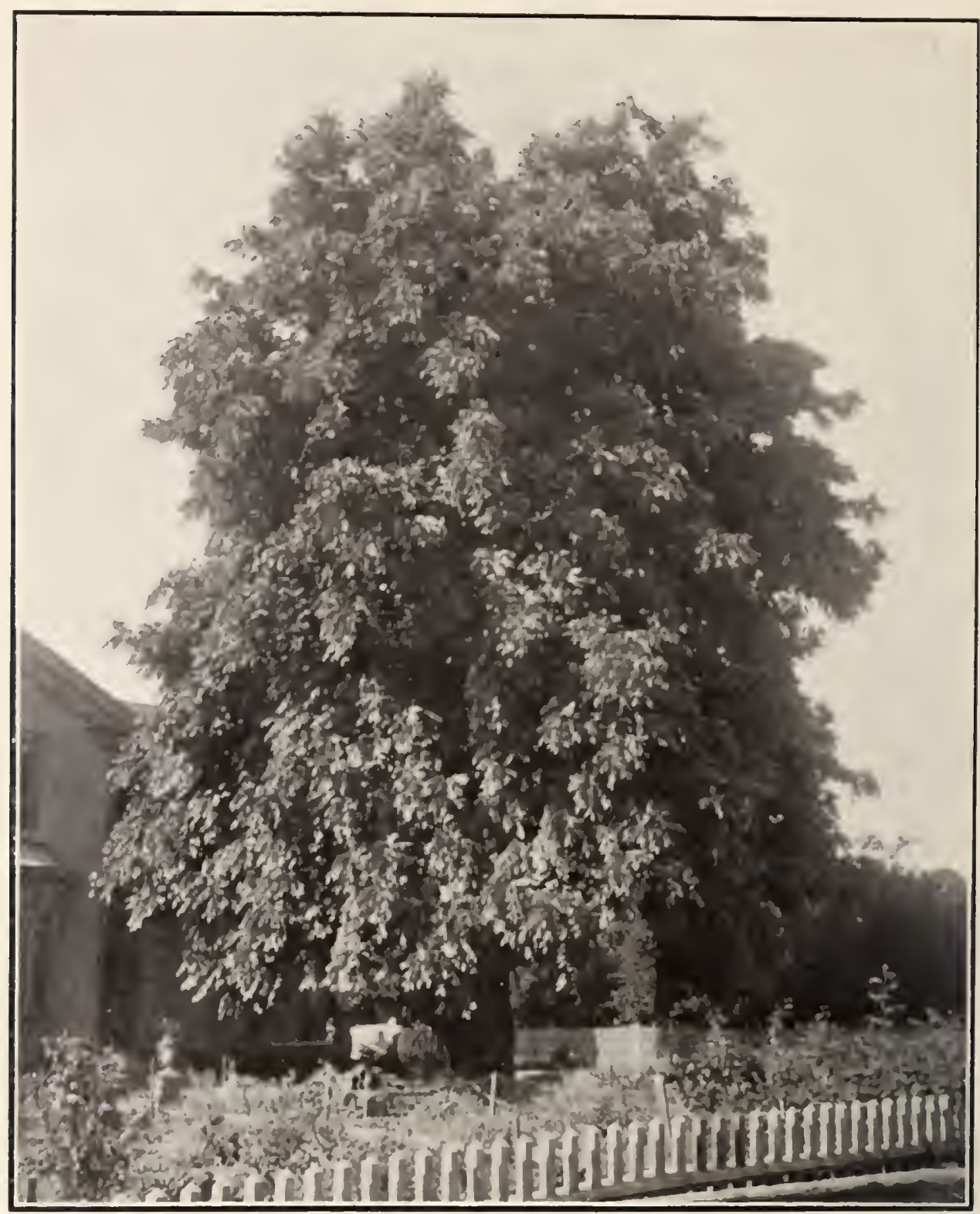

The Royal Black W'alnuı in Foliage.

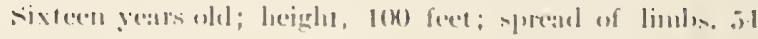
feet: trunk. 3 foet from the ground, is feet in diameter.

Seedlings versus (irafted Trees. The Royal IIahut was selected from thousands of secellinges ratied by Mr. Burbank as the thriftiest tree in the lot at the time he was experimenting in the development of a rapid-growing tree for tinsber purposes. The very fact that the scions from which our thees are grown, were 


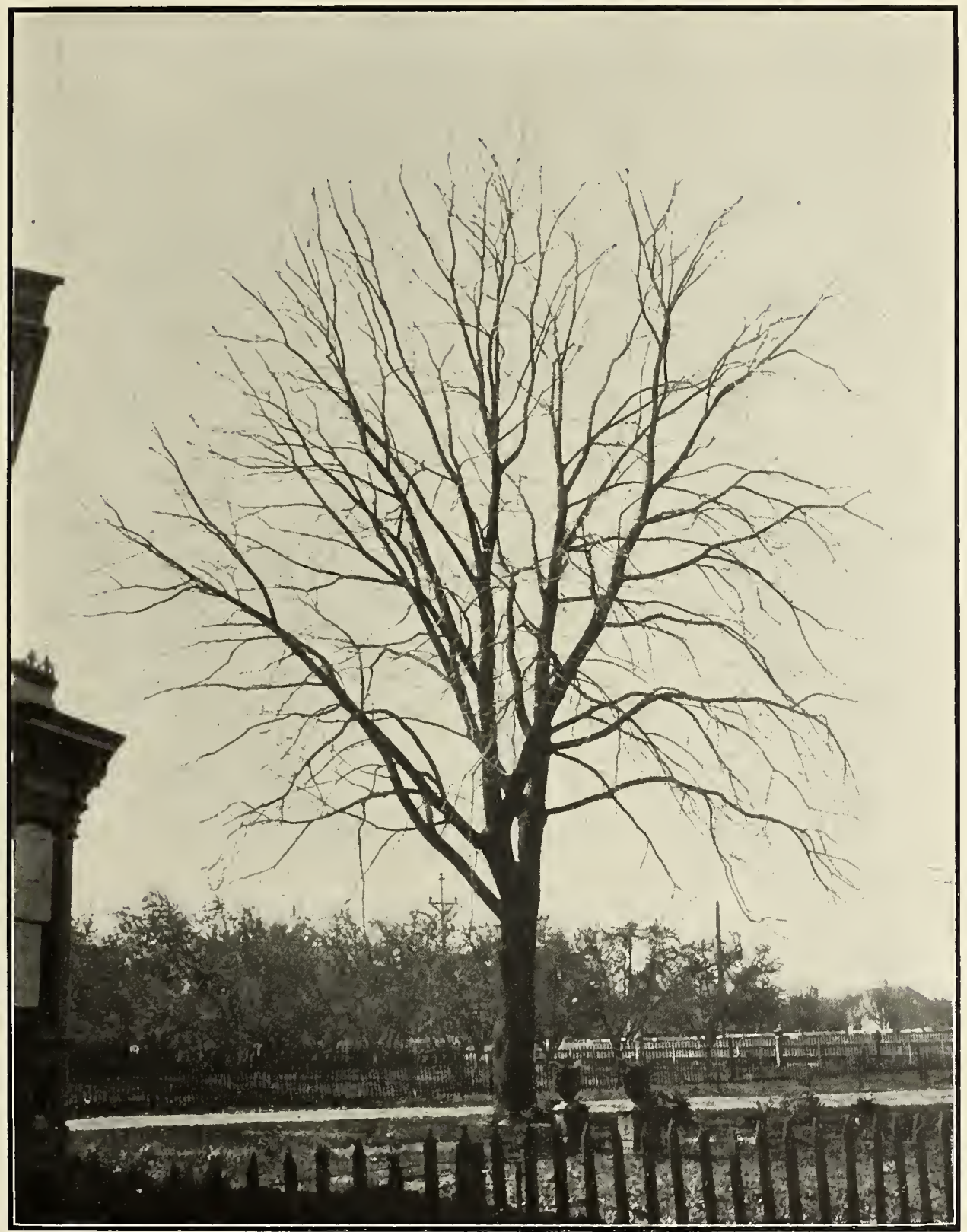

The Royal Black Walnut dormant

cut from this magnificent specimen, gives the purchasers the assurance that they are receiving trees true to the original type. Those purchasing seedlings must bear in mind that they may or may not equal the parent tree in rapidity of growth and habit. This is a chance taken by the purchaser. On the other hand with grafted trees, we can guarantee the trees we sell to be identical to the original tree. 
Nuts and Method of Planting. We will be pleased to supply muts as long as our supply lasts. In countries with clinatic conditions similar to those of Califorria, they can be stratified by burying them in damp sand or a hose alluvial soil about four inches deep. The nuts should remain in the bed until they show signs of sprouting, when they should be at once planted in nursery form, for one or two seasons, or still hetter, in their permanent locition. If phanterl in nursery rows, the nuts should not be set closer than eight inches and not leeper than two inches helow the surface of the soil. Ono objection to plant. ing in orehard form is the possibility of disturbing the nuts when cultivatine the wround, and also that all of the nuts may not grow, which means the unneessim! cultivation of a large amount of ground. It has been demonstrated tine and again that transplanted trees grow fully as rapidly as those raberl fron the nuts and which have not been disturbed. In planting, the protruding radicle, whith is the first evidence of growth, shoukl be pointed downwarl. In coldel elintates where the ground becomes frozen in the winter months. strutify in at shallow lox of sand or light alluvial or sandy soil, which should be moderately daup. Plate the box in a cellar or pit. Should there be any dunger of attacks loy ants, a liberal amount of wool ashes mixed with the soil will repel them. I) n not commenee stratifying in cold climates earlier than the middle of Febuary. Nuts received too late in the spring to permit their being stratified, should be scraked in wear could water for five or six days, wanging the water every day, and then planted out.

From Mr. Harwool's recent book on "New ('reations in Plant I.ifr" wre take the following paragraphs voicing the oprinions of lumbermen and wocelworkers:

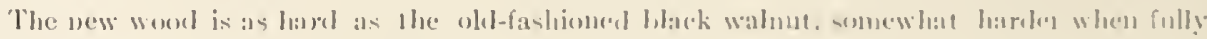
seisisucel

It has a finere grain than the old walume and lakes a higher polish.

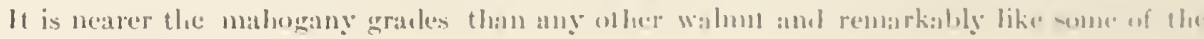
topic maloginies.

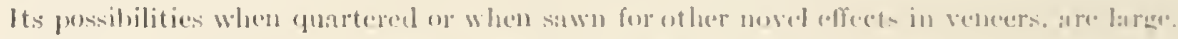

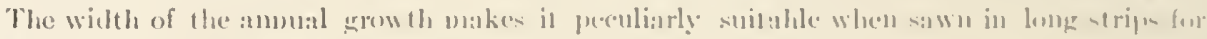
wainsorting and like effecels.

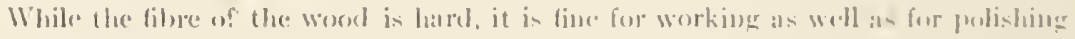

Under ordinary good conditions saw loges can be experterl at from eirht (1) twelve yeass of age from planting. like most of its family it makes a rat fuet show growth the first year after translanting but when once establishet. its growth is rapicl, firm, and at delight to the planter. By natue it prefers a decep athuvial soil, well drained. Indeed, the Roval will grow along side of and under the same conditions with the Ameriman Black Walnut of the Eastorn and Middle Western states. It will withstaml the same degree of frost and andhl. It is really ats hardy ats the oaks. 


\section{GOLDEN OPINIONS FROM EXPERTS}

\section{A Fine Canning Variety}

[From The National Nurseryman, August, 1907.]

The office of the Tational Nurseryman is in receipt of a box containing samples of Burbank'. Santa Rosa plum, forwarded by the Fancher Creek Nurseries, Fresno. This plum is of the largest size of its class. It is dark purplish-red in color, firm and meaty in flesh, with a moderate-sized stone which is adherent. The skin is tough, indicating good shipping qualities; the flaror is a curious mingling of Japanese and Prunus simoni qualities. There is, however, a good deal of acidity associated with the slin. We are of the opinion that it will prove a fine canning variety. The following is a more technical description of the specimens received:

Form, regularly round with truncate ends; size, large, two by one and seven-eights inches cavity, deep, narrow, flattened laterally; stem, one-half inch, slender; suture, well defined by a lidge, depression slight; apex, roundish, sometimes depressed; skin, smooth, tough, acid to astringeney; color, dull red with purplish tingc; dots, scattering, small, gray; bloom, none; juice, abundant colored; flesh, firm but melting, highly colored; stone, med. size, flat winged, cling with Americana characteristics; flavor, mild with peculiar prune flavor; quality, fair to medium; use, cooking.

General notes: This is a handsome fruit and appears to combine Japanese, Amcricana and Simoni charactistics. Keeps wetl.

Specimen received from Fancher Creek Nurseries, Fresno, Cal.; described by J. C.; date, July 16. '07; Phum, Ilybrid group.

\section{A Fine Eating Plum}

Fancher Creek Nurseries, Fresno, Cal.

Rochester, N. Y., August 10, 1907.

Gentlemen: We are mailing you today the August issue of the National Nurseryman and we trust that the notice given to your "Santa Rosa" plum will be satisfactory.

It was such a fine eating plum, that I would like to have you send me a peck of them, providing vou can ship them in as good a condition as the sample reccived. Kindly send bill for same. The Santa Rosa plum is certainly the finest tasting plum that I have ever eaten.

Awaiting your early reply, and with best wishes for your success, we are, Very truly yours,

THF NITION II, NURSERYMAN PUBLISHING CO.

C. L. Yates, Trens.

\section{Large, Showy, Handsome and Good Quality}

\section{Mr. George C. Roeding, Fresno, Cal.}

Rochester, N. Y., July 24, 1907.

Dear sir: The samples of Burbank's new plums sent on the 18 th were delivered here today, the 24th, in good condition. The three varieties: Santa Rosa, Gaviota and Formosa, are large, showy, handsome and of good quality. They seem to be very promising.

Thanking you for the opportunity afforded to test them. I am.

$$
\text { Yours truly }
$$

W. C. BARRY,

Of Ellwanger \& Barry, Nurserymen

\section{Quality Fine, Rich, Juicy and Sweet}

Mr. George C. Roeding, Fresno, Cal.

St. Louis, Mo., July 18, 1907.

Dear Sir: The box of Santa Rosa plums which you sent. July 8th, reached me July 13th. One specimen had just started to decay, all the others were in perfect condition. I have kept a few of them on my desk until today, and they have just started to show indication of decaying. It seems to me that this is a good indication of its carrying qualities.

The quality is very fine, rich, juicy and sweet. It appears to me to be a valuable addition to our various plums and especially so if it proves to be hardy and prolific bearer in more trying lnealities than the place of its origin.

Yours truly,

H. C. IRISH,

Of the National Council of Horticulture. 


\section{The Best in the Plum Line}



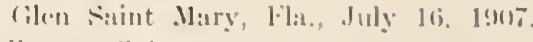

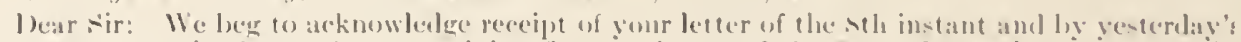

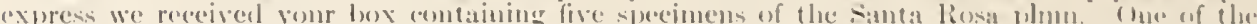

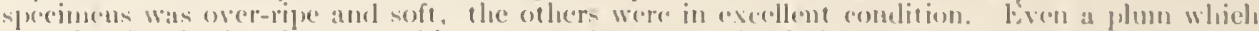

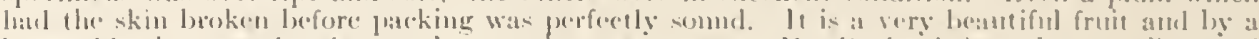

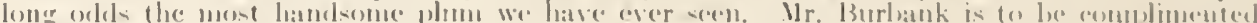

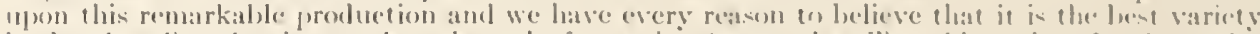

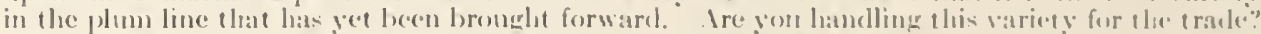

Thatnking you for sonding us the blums, with kimel regards, we remain. -incerely yours

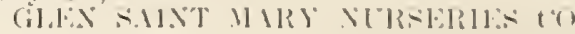

\section{A Great Acquisition}

Mr. Feoryf ('. Roudin!y, fresno, ('al.



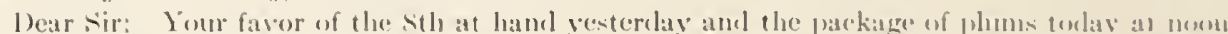

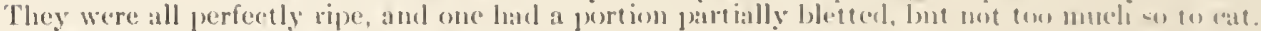

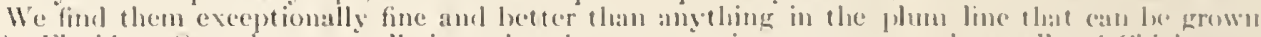

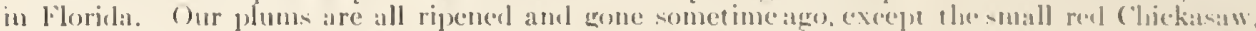

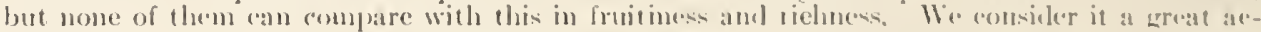
ypisition. livurs trily.

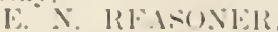

uf Resisuler Brothers. Nureryouen.

\section{Exceeds Anything of the Kind Ever Seen}

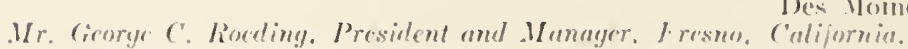

My bear sir: Your estecmed faror of the Isth inst.e allvising that you latel om that late expressed to me samples of burbank's new plums, was received on the "2:

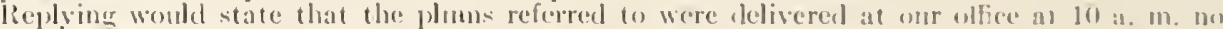
the 2:3ril, ats found to be firm and in exeellent comblition with but one exereption. (One of the

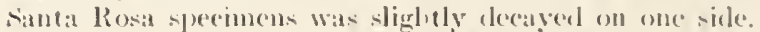

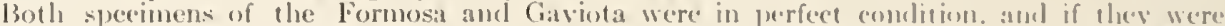

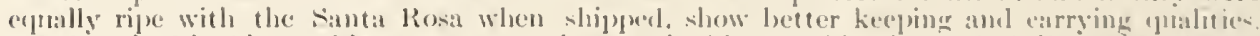

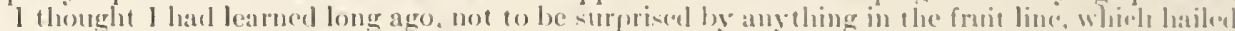
from ('alifornia; but these plums so far exceed amsthing of the kinel ever leefure seen, that I

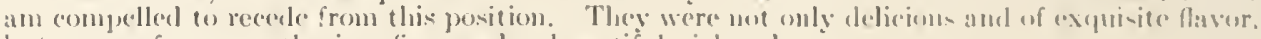
but wore of mammoth size, firm and a leatutifnl rich color.

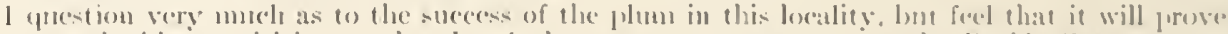
a very valuahle acquisition to the alreatle large assortment grown on the Paedie (atas.

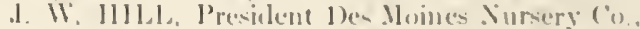

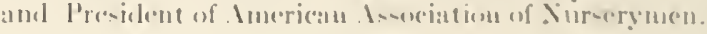

\section{One of Burbank's Best}

Georye C. Roudiny, Fresno, C'ol.

Siscramento, ("al., duly !) 1!1):

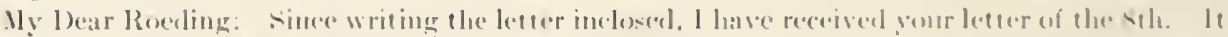

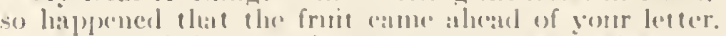

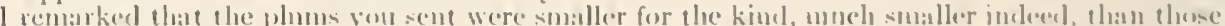

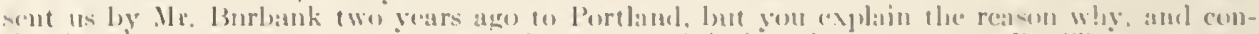

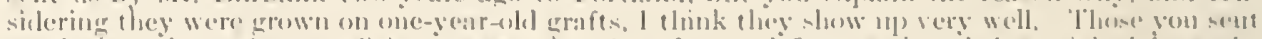

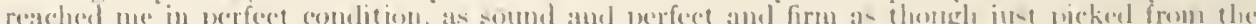

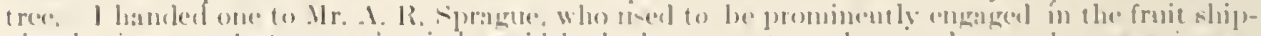

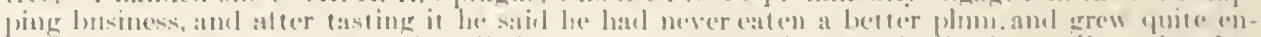

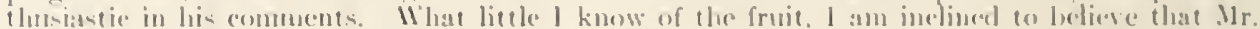

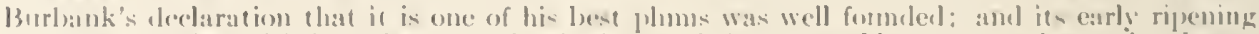

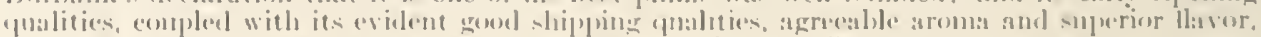

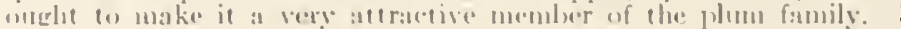

$$
\text { Y̌cos: very truls: }
$$




\section{Of Wonderful Quality}

Fancher Creek Nurseries, Fresno, Cal.

Tueson, Arizona, July 12, 1907.

Gentlemen: We received your half dezen Santa Rosa plums recently and were much interested in judging them. Although we happened to have no expert on plums present at that time, I think we are all quite unanimous in thinking them of wonderful quality. I cannot inagine a more luscious fruit of the plum tribe than this variety.

Thanking you for the opportunity to judge them, I am

Your's very truly,

R. H. FORBES,

of the University of Arizona.

\section{Plum is a "Peach"}

Niles, Cal., July 25, 1907.

Mr. George C. Roeding, President and Manager, Fancher Creek Nurseries, Fresno, Cal.

Answering yours of July 18th, we received by express the three samples of Burbank's new plums. Gaviota and Santa Rosa were in perfect condition; Formosa had collapsed and was very soft and overripe. We thought it of fair quality but inclined to be coarse-fleshed. We held the other two for a few days before cutting, to see how they would stand up. After being on our desk for three days we cut them and found Santa Rosa in good condition and : very fine plum, firm, of fine flavor, with the flesh dyed red about half way to the pit. We think it will ship well.

Gaviota, although a plum, is a "peach." In fact we think it is the finest plum we ever saw. We found it firm, with a very fine flavor and very much sweeter than the Santa Rosa. With its size, color. quality and small pit, we do not sec how it could be better.

Yours truly,

CALIFORNIA NURSERY COMPANY,

W. V. Eberly, Manager.

\section{Eating Quality of the Best}

Gcorge C. Roeding, Esq., Fresno, Cal.

Sacramento, Cal., July 12, 1907 .

Dear Sir: We note in yours of July 6 what you have to say about the Santa Rosa plum, and also want to acknowledge with our thanks, receipt of the samples of this fruit which you scnt us.

Personally, I can say without any hesitation, that the eating qualities of this plum are about as fine as any I have tasted. It is a good looker, both inside and out, and has good form. It ought to prove a dandy. Are you handling this exchusively?

ivith best personal regards, 1 remain,

Very truly yours,

H. C. ROWLEY,

Editor California Fruit Grower.

\section{Should Be Largely Planted}

\section{Mr. George C. Roeding, Fresno, Cal.}

Los Angeles, Cal., July 22, 1907.

Dear Sir: Your two letters and also two boxes, one containing "Santa Rosas" and the other containing "Rutland Plumeot" and "Formosa" plums, were all duly received, and have been exhibited to many who have visited this office. In fact the last ones were lield almost too long to give the best flavor to the fruit. Every one who examined them has been very much pleased with the appearance of the fruit, and as to the Santa Rosas the aroma which came from the box filled the whole room and was remarked by all who entered the office. The flavor is exquisite and we see no reason why this fruit should not be very largely planted over this State. Certainly in size and appearance they leave nothing wanting, and we wish for you a most suc cessful season with these trees. Yours very truly,

C'ULTIVATOR PUBLISHING CO.

\section{Nicely Blended With Pleasant Flavors}

Mr. Georye C. Roeding, Fresno, Cal.

Morgan Hill, Cal., July 21, 1907 .

Dear Sir: I was very pleased to receive the samples of Burbank's new plums. As I did not get them from the Express office until the evening of the 20th, and being sent from Fresno on the 18th, and all in good condition. speaks well for their carrying qualities, although I could not say much as to that, comparing with other varieties, not knowing when these samples were picked.

These plums all show marked improvement in quality over other named sorts of the class.

The fineness in grain of the Satsuma is nicely blended with the pleasant flavors of the Kiclsey and Burbank. "Santa Rosa" would be my choice, it having a more marked flavor, (similar to a Bartlett pear) than the other two.

Yours truly,
LEONARD COATES,
the Leonard Coates Nursery Co 


\section{PRICE LIST OF BURBANK'S \\ LATEST CREATIONS}

\section{OFFERED ONLY BY THE FANCHER CREEK NURSERIES.}

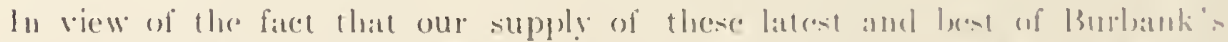

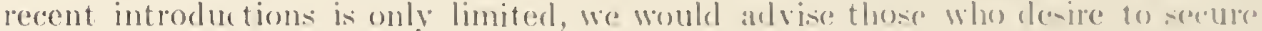
trees to plate their orders at an early date. The orders will he filled in rotation as received. When our stock is exhausted, we will not be in pusition to supply any more trees until next season.

On aceount of the scaucity of wood necessary for errafting. all the prest. offered with exeeption of Walnuts, are cut domin lo three feed and the latteral branches are shortened in to four inches.

\section{INTRODUCTIONS OF 1907-1908.}

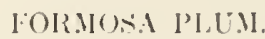

1 l'ear on Peuch root.

lisch lios to

G.ATOTA P'LU.

1 lear on Myrobolan lioot

VEIVILS.

1 lear on Peach liont

\section{INTRODUCTIONS OF 1906-1907.}

S.INT.I ROSA PILII.

I Vear on Peach :mol Myrobolan

1 Vear on P'each and Myrobolan.

Girafted on Native Black Wiblutut, f-6 ft

(irafted on Native l3lack Walnut, f-1; ft

\section{Fancher Creek Nurseries,}

GEO. C. ROEDING, 

ONLY AUTHORIZED DISTRIBUTORS

BURBANK'S LATE INTRODUCTIONS

Some New Varieties of Fruit and Forest Trees

offered to the public for the first time

\section{Fancher Creek Nurseries}

Fresno, California, United States of America

George C. Roeding, Pres't and Manager 